\title{
Integrated assessment of global water scarcity over the 21st century under multiple climate change mitigation policies
}

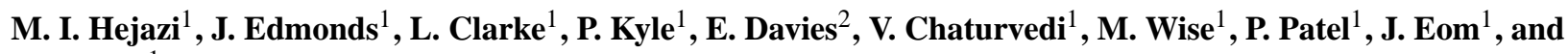 \\ K. Calvin ${ }^{1}$ \\ ${ }^{1}$ Joint Global Change Research Institute, Pacific Northwest National Laboratory, College Park, Maryland, USA \\ ${ }^{2}$ Department of Civil and Environmental Engineering, University of Alberta, Alberta, Canada \\ Correspondence to: M. I. Hejazi (mohamad.hejazi@pnnl.gov)
}

Received: 31 January 2013 - Published in Hydrol. Earth Syst. Sci. Discuss.: 13 March 2013

Revised: 11 June 2014 - Accepted: 16 June 2014 - Published: 6 August 2014

\begin{abstract}
Water scarcity conditions over the 21st century both globally and regionally are assessed in the context of climate change and climate mitigation policies, by estimating both water availability and water demand within the Global Change Assessment Model (GCAM), a leading communityintegrated assessment model of energy, agriculture, climate, and water. To quantify changes in future water availability, a new gridded water-balance global hydrologic model namely, the Global Water Availability Model (GWAM) - is developed and evaluated. Global water demands for six major demand sectors (irrigation, livestock, domestic, electricity generation, primary energy production, and manufacturing) are modeled in GCAM at the regional scale (14 geopolitical regions, 151 sub-regions) and then spatially downscaled to $0.5^{\circ} \times 0.5^{\circ}$ resolution to match the scale of GWAM. Using a baseline scenario (i.e., no climate change mitigation policy) with radiative forcing reaching $8.8 \mathrm{~W} \mathrm{~m}^{-2}$ (equivalent to the SRES A1Fi emission scenario) and three climate policy scenarios with increasing mitigation stringency of 7.7, 5.5 , and $4.2 \mathrm{~W} \mathrm{~m}^{-2}$ (equivalent to the SRES A2, B2, and B1 emission scenarios, respectively), we investigate the effects of emission mitigation policies on water scarcity. Two carbon tax regimes (a universal carbon tax (UCT) which includes land use change emissions, and a fossil fuel and industrial emissions carbon tax (FFICT) which excludes land use change emissions) are analyzed. The baseline scenario results in more than half of the world population living under extreme water scarcity by the end of the 21 st century. Additionally, in years 2050 and 2095, 36\% (28\%) and 44\% (39\%) of the global population, respectively, is projected to live in grid cells (in basins) that will experience greater water
\end{abstract}

demands than the amount of available water in a year (i.e., the water scarcity index (WSI) > 1.0). When comparing the climate policy scenarios to the baseline scenario while maintaining the same baseline socioeconomic assumptions, water scarcity declines under a UCT mitigation policy but increases with a FFICT mitigation scenario by the year 2095, particularly with more stringent climate mitigation targets. Under the FFICT scenario, water scarcity is projected to increase, driven by higher water demands for bio-energy crops.

\section{Introduction}

Struggling to understand the implications of global climate change, society has devoted considerable attention to assessing the potential consequences of climate change on different human and Earth systems, and to devising adaptation and mitigation policies to minimize any potentially dangerous anthropogenic consequences. To clarify the longerterm nature of connections between human and natural Earth systems, several high-resolution, interdisciplinary global integrated assessment (IA) models have emerged and contributed significantly to the Intergovernmental Panel on Climate Change (IPCC) climate change assessment reports. IA models currently focus on energy, agriculture, land use, and climate. However, all assessments to date have implicitly assumed that emissions mitigation and adaptation to climate change will be unaffected by water scarcity - yet water availability may pose a significant constraint on our ability to adapt to or mitigate climate change. As an example, global emission mitigation policies can significantly alter land use 
patterns, both by limiting land use change emissions, and by increasing bioenergy production. The future of bioenergy crops, an important component of many technology strategies to reduce greenhouse gas emissions, may depend critically on water (Berndes, 2008; Varghese, 2007; GerbensLeenes et al., 2009; Berndes, 2002). Thus, water availability could impose severe limitations on both emissions mitigation and climate adaptation, making the ability to assess the implications of changing supplies and demands for water - stemming from a simultaneously evolving human population, economic system, technology, and climate - an important scientific development.

With rapid shifts to socioeconomic systems, especially in the developing world, and potentially large-scale but varying impacts of climate change on global and regional hydrological cycles occurring simultaneously, an integrated assessment framework is expected to provide rich insights into alternative future global water demand and supply scenarios. Thus, any quantification of climate change impacts on water scarcity is incomplete without accounting for changes in both water availability and demands for humans. Several studies have assessed the impact of climate change on hydrology and water availability with a general consensus that runoff increases in higher latitudes and decreases in arid and semiarid regions with more frequent extremes due to an enhanced water cycle through warming (Milly et al., 2005). Yet, much uncertainty remains, especially with regard to GCM simulations used to force the hydrologic system, due the large differences in rainfall predictions.

Several global water management models coupled with global hydrologic models are also capable of producing water use estimates generally categorized in domestic, industrial, and agricultural sectors. However, there is potentially an infinite number of underlying assumptions that can replicate a particular emission scenario but induce vastly or somewhat different water demand projections. Future global water use estimates are generally driven by socioeconomic and technological change assumptions that reflect the storyline of the emission scenario producing the GCM climatic forcings (Alcamo et al., 2003b; Shen et al., 2008; Vörösmarty et al., 2000; Arnell, 2004) or by a set of assumptions representing a wide range of socioeconomic pathways (Hejazi et al., 2013b). However, future water demands can be affected by climate change mitigation policies (i.e., policies designed to reduce emissions of greenhouse gases (GHGs)), which could feed back to affect the land and energy systems, and subsequently global water supply and demands (Falkenmark, 1999; Vörösmarty et al., 2000; Jackson et al., 2001). In this paper, we quantify the effect of various climate change mitigation policies on global and regional water demands and scarcity conditions.

Several authors have assessed water scarcity conditions both globally and regionally at various spatial (e.g., grid, county, basin, country) and temporal (e.g., monthly, annual) scales (Oki et al., 2001; Alcamo and Henrichs, 2002; Islam et al., 2007; Viviroli et al., 2007; Shen et al., 2008; Wada et al., 2011; Hayashi et al., 2013) with estimates of about one-third of world population currently living in water-scarce countries (WMO, 1997). Several studies have also assessed water scarcity conditions in the future, with water demands modeled as a function of socioeconomic assumptions, and water availability derived using climate models (Arnell, 1999a, 2004; Vörösmarty et al., 2000; Alcamo et al. , 2003b, 2007). However, only one study has investigated the implications of climate policy on global water scarcity (Arnell et al., 2011). Arnell et al. (2011) compares the percentage of the population living in scarce areas under a baseline scenario (no climate policy) and a climate mitigation of policy of $450 \mathrm{ppm}$ $\mathrm{CO}_{2}$ e (equivalent carbon dioxide) by 2100 . In this paper, we follow a similar approach by studying the effect of different types and levels of climate change mitigation policies. Instead of linking results from a set of models like Arnell et al.'s (2011) study - which used the IMAGE model and Shen et al.'s (2008) water withdrawals - we use linked water demand and supply modules incorporated within an IA model to ensure consistency and the ability to pinpoint the system components responsible for any important observed changes. This capability can provide greater insight about the implications of climate policies on the dynamics of natural Earth systems and help to identify important technological investment and adaptation measures.

The primary goal in this study is to quantify, in an integrated framework, the effects of climate mitigation policies on global and regional water scarcity estimates, while accounting for uncertainty arising from using different GCMs and following different types and constraining levels of climate policies on water scarcity. Toward that goal, it is essential to model water demand and supply in a unified and internally consistent integrated assessment framework that captures the inter-linkages and feedbacks with other natural and human systems, which can be exceptionally useful to assess the current and future picture of both global and regional water scarcity more accurately. This integrated modeling framework facilitates estimation of water resources demands and supplies globally and regionally by explicitly modeling the effects and feedbacks of both natural processes (climate model, crop model, and land use model) and human systems (anthropogenic forcing, land use change, energy demands and technologies, socioeconomics, and market-based economies). Thus, in this study, we incorporate a new gridded water-balance global hydrologic model (GWAM) as a new component to the GCAM water system, and combine it with spatially downscaled representations of all the existing water demand sectors (Hejazi et al., 2013a, b; Chaturvedi et al., 2013; Davies et al., 2013) in GCAM to produce a dynamic, high-resolution view of global, annual water scarcity.

Next, we briefly describe GCAM. Then we present the methods of modeling global water availability and demands in GCAM, with special attention to the downscaling techniques. 


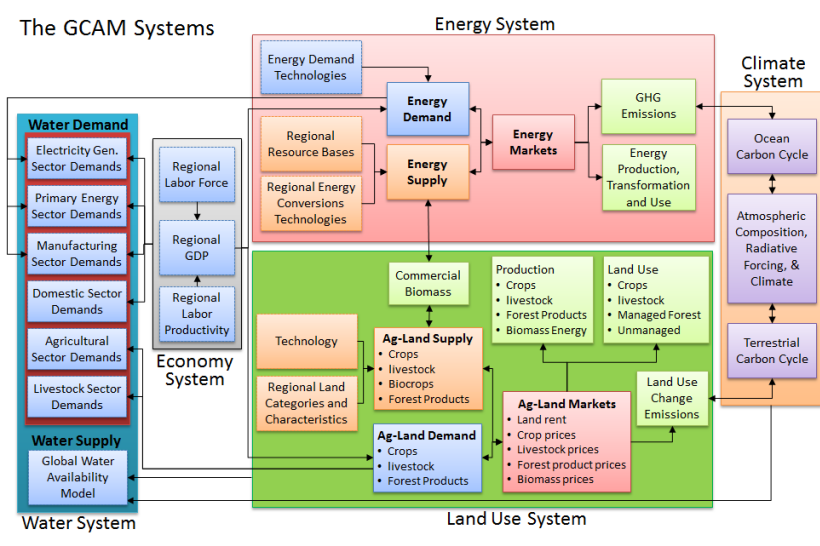

Figure 1. Schematic of the GCAM systems with links to the water system.

\section{GCAM}

The Global Change Assessment Model (GCAM) has played a central role in the United States and international assessment processes since its inception (Edmonds and Reilly, 1985; Clarke et al., 2007; Kim et al., 2006; Brenkert et al., 2003). GCAM is a dynamic-recursive model combining representations of the global economy, the energy system, agriculture and land use, and climate. Exogenous inputs include (among other variables) present and future population, labor productivity, energy and agricultural technology characteristics, and resource availabilities. In its current implementation, GCAM has the following 14 geopolitical regions: the United States, Canada, western Europe, Japan, Australia \& New Zealand, former Soviet Union, eastern Europe, Latin America, Africa, Middle East, China [\& Asian reforming economies], India, South Korea, and the rest of South \& East Asia. The model is calibrated to historical energy, agricultural, land, and climate data through the 2005 time period, and runs in 5-year time steps to 2095, establishing marketclearing prices for all energy, agriculture, and land markets such that supplies and demands of all modeled markets are in equilibrium. GCAM traditionally includes representations of the economic, energy, and land use systems, and uses the Model for the Assessment of Greenhouse-gas Induced Climate Change (MAGICC) (Raper et al., 1996; Wigley and Raper, 1992, 2002) as its reduced-form representation of the atmosphere, ocean and climate systems. The water system including both demand and supply are incorporated into GCAM as shown in Fig. 1. In the current GCAM form, water does not hold any monetary value, and when demand exceeds the water availability, additional supply is assumed to come from non-renewable groundwater.

\section{Global Water Availability Model (GWAM)}

\subsection{Background}

For assessment of climate impacts on water, general circulation models (GCMs) and their representation of the hydrologic cycle are often used to provide spatially and temporally explicit quantification of changes in the water system over the upcoming century. The first such numerical parameterization of the hydrologic cycle within a GCM was done by Manabe (1969). However, the initially simplistic and coarse representation of the hydrologic cycle within a GCM resulted in poor hydrologic predictive skill (Kuhl and Miller, 1992; Miller and Russell, 1992). To alleviate this shortcoming, GCMs have utilized land surface models (LSMs) with hydrologic capabilities to improve the representation of runoff. Oki et al. $(1999,2001)$ argued that current LSMs can simulate monthly river runoff quite well, provided that the precipitation and other climate forcing input data for the LSMs are sufficiently accurate. However, many LSMs still remain too coarse to capture some underlying hydrologic processes. Thus, a group of sub-grid parameterization LSMs have emerged (e.g., VIC (Liang et al., 1994, 1996), SIMTOP (Niu et al., 2005), and GBHM (Yang et al., 2001)). This group of models generally represents the sub-grid variability (in soil moisture storage capacity, topography, and/or vegetation) as a spatial probability distribution.

An alternative is the emergence of a family of global water-balance models (WBM/WBMplus (Vörösmarty et al., 1998, 1989), WATBAL (Kaczmarek, 1993; Yates, 1994, 1996), WaterGAP (Alcamo et al., 2003a, 1997), macroPDM (Arnell, 1999b), IMPACT-WATER (Cai and Rosegrant, 2002), FAO's model (Bruinsma, 2003), LPJ/LPJmL (Gerten et al., 2004; Rost et al., 2008), GEPIC (Liu et al., 2007, 2009; Liu and Yang, 2010), WASMOD-M (Widén-Nilsson et al., 2007), WATERSIM (de Fraiture, 2007), H08 (Hanasaki et al., 2008a, b), and PCR-GLOBWB (Sperna Weiland et al., 2010) that improve the ability to simulate water availability on a global scale from GCM climatic forcings. Those models have evolved from a vertical water balance at the grid scale (typically $0.5 \times 0.5$ ), to routing water spatially from one grid cell to another, incorporating crop growth models, and modeling global water management components (e.g., reservoir management, human water use). However, not all such models incorporate all of these details, and they vary with regard to temporal and spatial scale, runoff mechanism, crop growth modeling scheme, and the representation of human systems. In general, global water balance models compute the water fluxes and related processes, and employ soil water balances based on climate, land cover (cropland, pasture, natural vegetation) and soil information on a grid cell basis, typically at $0.5^{\circ}$ resolution. In several of the models that focus on agriculture, soil moisture thresholds are set according to the irrigation triggered. Some models, such as GEPIC, extend further to include nutrient cycling, tillage and agronomics, 
simulating the effects of different agricultural management options (Hoff et al., 2010). Some models (GEPIC, LPJmL) internally calculate crop yields, while other models (GCWM, WBMplus) use (mostly country-based) crop production data from agricultural statistics. In this study, the latter approach is used.

Water balance models typically use monthly climate data from the Climate Research Unit (CRU, University of East Anglia) to simulate the hydrologic processes, but some models temporally downscale the climate input data to daily scale to better model crop growth and irrigation water demand. Land use is generally based on the Ramankutty et al. (2008) distribution and extent of cropland and permanent pasture. Areas equipped for irrigation are generally taken from Siebert et al. (2007) and crop types from Monfreda et al. (2008) or Portmann et al. (2008). Generally, land use is assumed constant over the duration of the simulation period. Furthermore, different approaches for calculating potential evapotranspiration (PET) are typically used in different models, e.g., Penman-Monteith (GCWM), PriestleyTaylor (GCWM, IMPACT, LPJmL, WaterGap), Hargreaves (GEPIC), Hamon (WBMplus), or bulk formulas (H08). Zomer et al. (2006) applied five methods of estimating potential evapotranspiration to South America and Africa and found that the Hargreaves method (Hargreaves et al., 1985) compared favorably with the FAO Penman-Monteith, but required less parameterization, and with improved robustness to error in climatic inputs (Hargreaves and Allen, 2003). Thus, to determine agricultural water consumption in this study, we use the Hargreaves method.

\subsection{Model overview}

In this study, a global hydrologic model, GWAM, is constructed and evaluated. GWAM is designed to retain consistency with the approaches used in current state-of-theart hydrological models, but with several modifications and simplifications in order to allow incorporation into GCAM. Components that are excluded in GWAM (as compared to most existing global hydrologic models) are river and reservoir routing, and a crop growth model that is simulated at the same temporal and spatial scale as the hydrology model. The former component is generally an important feature to achieve accurate monthly estimates of runoff, but it is less crucial when accounting for water on an annual basis and over very large first-order basins that drain directly into nonfreshwater bodies. This study incorporates a crop model similar to the FAO approach (FAO, 2001) since the agricultural water demand module is repeatedly calculated as GCAM solves all the markets in a particular time period, thus reducing the computational burden tremendously.

GWAM reproduces historical streamflow observations and simulates the future availability of freshwater under both a changing climate and an evolving landscape with competing water users. The model is grid-based, with a spatial resolu- tion of $0.5^{\circ} \times 0.5^{\circ}$, and a monthly time step. Water routing capabilities and reservoir operation rules are not included. The water supply model is first evaluated against observational data and other models, and then simulated into the future to provide estimates of total water supply up to the end of the 21 st century.

The global water availability model provides estimates of renewable freshwater resources in the form of surface flow. This indicates the maximum theoretical amount of water naturally available in a year for each of the basins. In reality, some of the runoff flows too quickly to saline water bodies or occurs in remote areas where there is no potential for people to use it. Thus, almost all recent studies have assessed water scarcity conditions using water scarcity indices such as that of Falkenmark (Falkenmark, 1989) and Raskin (Raskin et al., 1997). Falkenmark (1989) assumes that a country or region experiences some water stress when annual water supplies drop below 1700 cubic meters per person per year, and faces water scarcity when they drop below 1000 cubic meters per person per year. Raskin et al. (1997) compare total water demand to the total amount of renewable water available, and define extreme water scarcity in any region as demand in excess of $40 \%$ of total water availability; Wada et al. (2011) provide a detailed summary of previous studies that have used the definition of Raskin. In regions where the total water demands exceed the total stable flow of renewable water, humans have tapped into other sources that are either quite expensive (desalination of brackish and saline water) or unsustainable (fossil groundwater abstractions) (Wada et al., 2010; Gleeson et al., 2012). In this paper, we only consider renewable water resources (i.e., annual flow of rivers) in the water scarcity calculations.

\subsection{Model structure}

The Global Water Availability Model (GWAM) is a gridded monthly water balance model with a resolution of $0.5^{\circ} \times 0.5^{\circ}$ (Fig. S1 in the Supplement). It requires gridded monthly precipitation, temperature, and maximum soil water storage capacity (a function of land cover), and computes the amounts of evapotranspiration to the atmosphere, runoff, and soil moisture in the soil column. The model structure is consistent with existing global water balance models, and with the FAO's model formulation for modeling water resources in Africa (FAO, 2001). GWAM tracks the fraction of rainfall that feeds into the soil column (green water) and runoff (blue water) at a monthly scale. The model accounts for the monthly green water storage and estimates the fraction of green and blue water that is evaporated back to the atmosphere through evapotranspiration from vegetation and cultivated lands and evaporation from bare soil or water bodies. The maximum soil moisture storage capacity $\left(S_{\mathrm{m}}\right)$ with a resolution of $0.5^{\circ} \times 0.5^{\circ}$ is obtained from the soil map of the world and soil properties (FAO, 1998, 2003). Information with regard to the maximum soil moisture storage 
capacity in $\mathrm{mm} \mathrm{m}^{-1}$ is derived from the derived soil properties of the Digital Soil Map of the World, which contains raster information on soil moisture in different classes (FAO, 1998, 2003). Maximum available soil moisture is estimated from estimates of root depth, field capacity, and wilting point values (typically ranges between $15-350 \mathrm{~mm} \mathrm{~m}^{-1}$ ). The root depth estimate is itself a function of land cover and water stress conditions. In this study, a static $S_{\mathrm{m}}$ map over time is assumed.

As with any water balance model, the conservation of mass is observed following Eq. (1). That is, the amount of storage in the soil column $\left(S_{t}\right)$ is the sum of initially available water in storage $\left(S_{t-1}\right)$ plus the amount of precipitation that falls during the month, minus the amount of water that evaporates back to the atmosphere through evaporation from water bodies or the soil, or through transpiration from vegetation $\left(\mathrm{AET}_{t}\right)$ and the amount of runoff $\left(Q_{t}\right)$ during the month $t$.

$S_{t}=S_{t-1}+P_{t}-\mathrm{AET}_{t}-Q_{t}$

More specifically, for any given month and grid cell, the amount of water available in any month $t$ is a function of the amount of new precipitation $P_{t}$, the amount of water available in storage $S_{t-1}$, and potential evapotranspiration $\mathrm{PET}_{t}$. However, the amount of water actually returned to the atmosphere is generally less than the amount potentially available due to water stresses; i.e., the amount of water available in the soil column is less than the estimated $\mathrm{PET}_{t}$ value in a particular grid (an effect particularly apparent in desert and semiarid regions). Thus, the amount of actual evapotranspiration $\left(\mathrm{AET}_{t}\right)$ is modeled in theory as a function (Eq. 2) of the potential evapotranspiration as derived from climatic forcings, adjusted based on the water availability in a particular grid for a particular month. A nonlinear equation (Eq. 3) is used to determine actual evapotranspiration as a function of PET and the relative soil moisture state in a grid cell, according to Kaczmarek (1993).

$\mathrm{AET}_{t}=\beta \cdot \mathrm{PET}_{t}$

$\beta=\left(\frac{5 \cdot\left(\frac{S_{t-1}}{S_{\mathrm{m}}}\right)-2 \cdot\left(\frac{S_{t-1}}{S_{\mathrm{m}}}\right)^{2}}{3}\right)$

In practice, we estimate $\mathrm{AET}_{t}$ following Eq. (4).

$\mathrm{AET}_{t}=\left\{\begin{array}{cc}\mathrm{PET}_{t} & S_{t-1}+P_{t}-\mathrm{PET}_{t} \geq S_{\mathrm{m}} \\ \beta \cdot \mathrm{PET}_{t} & 0 \leq S_{t-1}+P_{t}-\beta \cdot \mathrm{PET}_{t}<S_{\mathrm{m}} \\ S_{t-1}+P_{t} & S_{t-1}+P_{t}-\beta \cdot \mathrm{PET}_{t}<0 \\ 0.1 \cdot \mathrm{PET}_{t} & \beta \leq 0.1\end{array}\right.$

Once $\mathrm{AET}_{t}$ is estimated, the current amount of storage can be computed following Eq. (5).

$S_{t}=\left\{\begin{array}{cc}S_{\mathrm{m}} & S_{t-1}+P_{t}-\mathrm{PET}_{t} \geq S_{\mathrm{m}} \\ \gamma \cdot S_{t-1}+P_{t}-\mathrm{AET}_{t} & \gamma \cdot S_{t-1}+P_{t}-\mathrm{AET}_{t}<0 \\ 0 & \gamma\end{array}\right.$, where $\gamma$ is a unitless drying function of the soil column following the WBM formulation (Vörösmarty et al., 1998).

$\gamma=\left(\frac{1-e^{-\alpha \frac{S_{t-1}}{S_{\mathrm{m}}}}}{1-e^{-\alpha}}\right)$

where $\alpha$ is an empirical constant (set to 1.0) and $\gamma$ is the soil and vegetation-dependent available water capacity (Vörösmarty et al., 1998).

Finally, having estimated $\mathrm{AET}_{t}$ and $S_{t}$ and given the values of $S_{t-1}$ (estimated in previous time step) and $P_{t}$ (an input variable), Eq. (1) can be rearranged to compute $Q_{t}$.

$Q_{t}=S_{t-1}+P_{t}-\mathrm{AET}_{t}-S_{t}$

Then the storage value of each grid cell is updated, the time index is incremented by 1 month, and the calculation procedure is repeated until the end of the simulation period. Figure S2 in the Supplement shows a detailed flowchart schematic of the model calculation algorithm. Details of calculating monthly PET (Hargreaves method) are summarized in Appendix A.

To simulate GWAM both historically (1901-2002) and in the future (2001-2100), gridded monthly climatic input variables are taken from the Climate Research Unit (CRU TS 2.0 (Mitchell et al., 2004)), and from the Tyndall Centre for Climate Change Research (TYN SC 2.1 (Mitchell and Jones, 2005)), respectively, both at the University of East Anglia.

\subsection{Model evaluation}

Prior to simulating GWAM into the future, the model ability to reproduce historical values is evaluated against observations, statistical assessments, and other global hydrologic models. Globally, the mean annual runoff of $38587 \mathrm{~km}^{3} \mathrm{yr}^{-1}$ is similar to previous data-based and model-based estimates, as shown in Fig. S3 in the Supplement. Figure S4 in the Supplement shows a comparison between our average annual runoff at the continental scale with other data-based and model estimates. The simulated global and continental mean annual runoff ranges correspond to the ranges of previous studies. The range bar around our estimates denotes the maximum and minimum annual runoff during the historical simulation period (1901-2002) for the global (Fig. S3 in the Supplement) and continental (Fig. S4 in the Supplement) scales. Note that, globally, data-based estimates are higher on average than model-based estimates. The observed difference at the global and continental scales can arise due to variations in the simulation period and modeling approach. Discrepancies may also arise due to inconsistency of spatial coverage. For example, data-based estimates generally cover small islands, while model-based estimates ignore those regions due to lack of appropriate spatial resolution, as is the case with GWAM's scale of $0.5^{\circ} \times 0.5^{\circ}$, which is generally too coarse to model small islands. Furthermore, some studies, including 

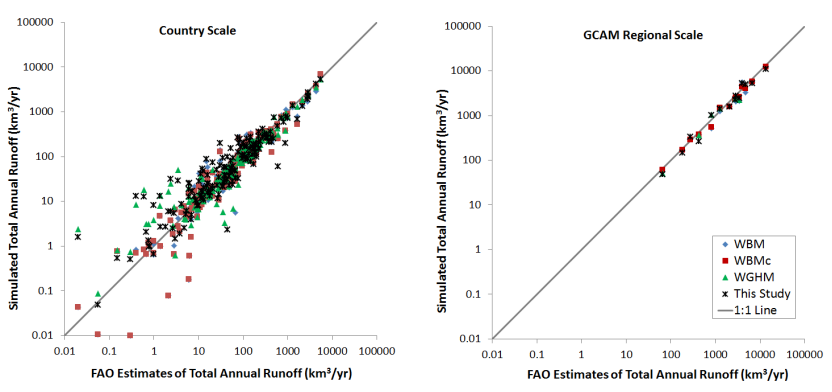

Figure 2. Comparison of this study's runoff volumes to FAO and other model-based estimates (e.g., WBM, WBMc, and WGHM) at the country and GCAM regional scales.

ours, do not include Greenland or Antarctica in the global and continental estimates. One additional source of variation at the continental scale may be due to how different studies split Russia between Asia and Europe. Table 1 summarizes the global and continental estimates from the literature.

Next, we compare our results in Fig. 2 with those of several other global hydrologic models (e.g., WBM (Fekete et al., 2000), WBMc (Fekete et al., 2000), and WGHM (Döll and Fiedler, 2008)), and with the FAO AQUASTAT estimates of renewable water resources by country, aggregated by GCAM regions in the year 2005 (AQUASTAT, 2012). Specific estimates for the country and GCAM regional scales are summarized in Tables 1 and S1 in the Supplement, respectively. Table 2 presents estimates of the models' departure from FAO's estimates at the country scale (only countries for which all four models have values are used) and the GCAM regional scale; model departure is measured in terms of root mean squared error (RMSE). Overall, all models exhibit a similar range of goodness-of-fit (Table 3). Variations among the models may be due to variations in the representation of rainfall-runoff generation and how PET is computed.

Finally, we compare our simulation results of historical average annual runoff for 29 major basins of the world against observed values from the Global Runoff Data Centre (GRDC, 1999) - see Tables S2 and S3 in the Supplement for a complete summary of our results in comparison with several other data-based and model-based estimates. Figure 3 shows a scatter plot of the basin scale results in comparison to several other model results. Overall, models tend to overestimate small annual runoff values for the selected basins. Variations again could arise due to several factors. Delineated drainage areas are somewhat inconsistent and area differences are relatively large for some basins (this is not a concern for the comparison with WBM and WBMc because they use the same drainage areas). Second, the time of record and simulation periods differ across sources. Third, this study assumes natural conditions while observed runoff data capture other factors (e.g., human activities). Thus, GWAM generally overestimates water availability (i.e., annual runoff) as compared with observed data in basins where water consump-

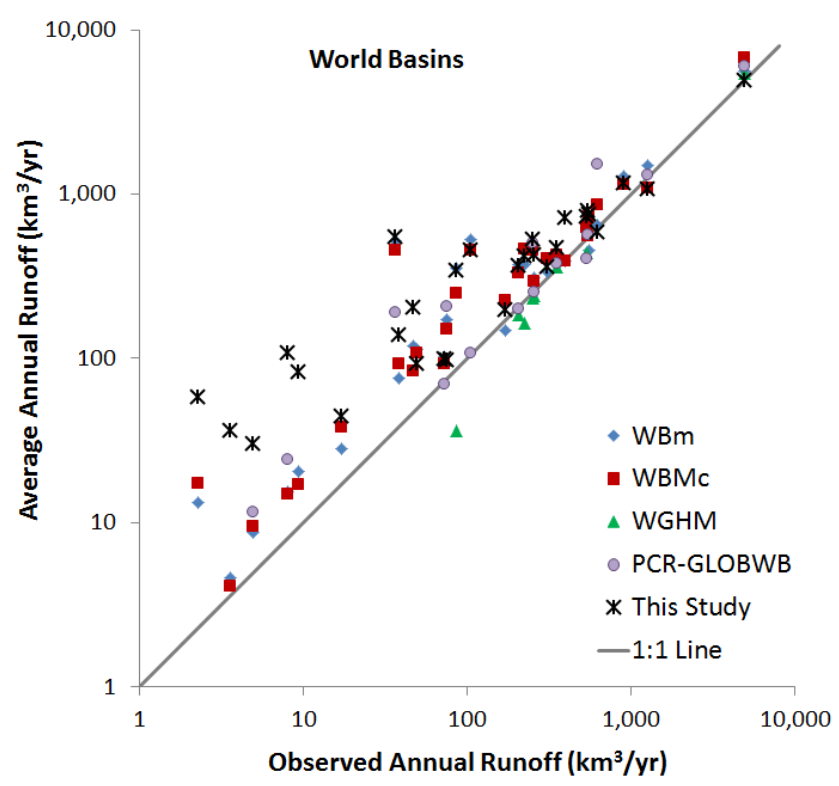

Figure 3. Comparing simulated runoff for the major basins of the world against observed values (from GRDC).

tion is extensive (especially agricultural water consumption) relative to water supply.

\subsection{GWAM future simulations}

GWAM is simulated over the entire 21 st century using the SRES (2000) A1Fi, A2, B1, and B2 emission scenarios and data from four GCMs (HadCM3, CSIRO2, CGCM2, PCM) (TYN SC 2.1; Mitchell and Jones, 2005) to result in 16 individual simulations of GWAM (4 GCMs $\times 4$ emission scenarios). In this study, we use the GCM ensemble mean annual runoff to establish the amount of maximum theoretically available renewable water at any grid cell in any month. GCM data are also used to quantify the effect of climate model uncertainty on the amount of water availability, and subsequently, water scarcity conditions. Next we describe the global water demand model.

\section{GCAM - Global Water Demand Model (GWDM)}

\subsection{Model overview}

Recently, Hejazi et al. (2013b) explicitly incorporated sectoral water demand modules within the framework of GCAM to estimate the amount of freshwater demanded on an annual basis. The water demand modules account for water use for irrigation, livestock, domestic purposes, electricity generation, primary energy production, and manufacturing. The modules have been constructed, calibrated, and evaluated (Hejazi et al., 2013b). Future agricultural water demands are driven by crop production from GCAM and the share of crop production that takes place on irrigated lands, 
Table 1. Summary of literature estimates of global mean annual runoff using both models and data-based estimates at both the global and continental scales.

\begin{tabular}{lrrrrrrrl}
\hline Reference & Europe & $\begin{array}{r}\text { North } \\
\text { America }\end{array}$ & Africa & Asia & $\begin{array}{r}\text { South } \\
\text { America }\end{array}$ & Oceania & Global & Data/ \\
Baumgartner and Reichel (1975) & 2564 & 5840 & 3409 & 12467 & 11039 & 2394 & 37713 & Data \\
Korzun et al. (1978) & 2970 & 8180 & 4600 & 14100 & 12200 & 2510 & 44560 & Data \\
Lvovich (1979) & 3110 & 5960 & 4225 & 13190 & 10380 & 1965 & 38830 & Data \\
WMO (1997) & 2900 & 7890 & 4050 & 13510 & 12030 & 2404 & 42784 & Data \\
Shiklomanov (1997) & 2900 & 7770 & 4040 & 13508 & 12030 & 2400 & 42648 & Data \\
GRDC (2004) & 3083 & 6294 & 3690 & 13848 & 11897 & 1722 & 40533 & Data \\
WRI (2005) & 6591 & 7461 & & & 12380 & 1693 & 43219 & Data \\
FAO (AQUASTAT 2010) & 6548 & 6858 & 3931 & 12413 & 12380 & 892 & 43022 & Data \\
\hline Oki et al. (2001) & 2191 & 3824 & 3616 & 9385 & 8789 & 1680 & 29485 & LSM-TRIP \\
Weiland et al. (2010) & 2175 & 4803 & 5099 & 10572 & 10678 & 2371 & 35698 & GCM ensemble \\
\hline Alcamo et al. (1997) & & 4333 & 4057 & & 10471 & & 33973 & WaterGAP1 \\
Cogley (1998) & & & & & & & 42353 & Data \\
Fekete et al. (2000) & 2822 & 5396 & 5567 & 11425 & 11240 & 1308 & 37758 & WBM \\
Fekete et al. (2002) & 2772 & 5892 & 4517 & 13091 & 11715 & 1320 & 39307 & WBMc \\
Doll et al. (2003) & 2763 & 5540 & 3529 & 11234 & 11382 & 2239 & 36687 & GWHM \\
Gerten et al. (2004) & & & & & & & 40143 & LPJ \\
Widén-Nilsson et al. (2007) & 3669 & 7009 & 3738 & 13611 & 9448 & 1129 & 38605 & WASMOD-M \\
Doll and Fiedler (2008) & 3104 & 6493 & 4065 & 13168 & 11310 & 1272 & 39414 & WGHM \\
Weiland et al. (2010) & 2143 & 5249 & 5573 & 11461 & 11186 & 2633 & 38245 & PCR-GLOBWB \\
Hanasaki et al. (2010) & & & & & & & 41820 & H08 \\
This study & 3194 & 6108 & 5217 & 13066 & 9854 & 1148 & 38587 & GWAM \\
\hline
\end{tabular}

by up to 18 agro-ecological zones (AEZ) within 14 geopolitical regions (151 sub-regions), and by crop type (12 types) - see Chaturvedi et al. (2013) and Hejazi et al. (2013b) for greater details. Future manufacturing and domestic water demands (Hejazi et al., 2013a) are driven by scenario-specific socioeconomic assumptions (e.g., population, GDP), among other factors. Water demands for primary energy are scaled with the amount of each fuel produced, and water demands for secondary energy (electricity, refined liquid products) depend on the specific production technologies used. In the electric sector in particular, water use depends not only on the generation technology mix, but also on the types of cooling systems used, for which we make explicit assumptions (see Davies et al., 2013). Thus, in this study, water demands are modeled for the agricultural, industrial, and municipal sectors, using technology-based representations where possible. Figure 1 shows how each of the six water demand sectors are linked to the existing systems in GCAM.

Next, we downscale the GCAM water demand results to grid scale using available spatial assessments of population, livestock, and irrigation.

\subsection{Spatial downscaling to grid scale}

A fundamental step in this study is to link the global water supply and demand models described above to GCAM's existing energy, agricultural, and socioeconomic systems.
However, the spatial resolution of these existing systems in GCAM is not adequate for detailed analysis of the water system; to link these systems, spatial downscaling of GCAM output is necessary. In this paper, we separately downscale irrigation water demands, livestock water demands, and all remaining water demands (e.g., municipal, electricity generation, primary energy, and manufacturing water demands). For the latter, we use population to downscale water demand estimates from the 14 GCAM regions to the grid scale $\left(0.5^{\circ} \times 0.5^{\circ}\right)$. Using the WWDR-II population data (Elvidge et al., 1997a, b; ESRI, 1993; Tobler et al., 1995) and following the work of Wada et al. (2011), the population gridded map is converted to population density maps, i.e., the sum of all grids within each GCAM region adds up to 100 percent. Assuming that population density maps remain static over time within each GCAM region, and using the population projections for each GCAM region, a global map of gridded population is generated for every GCAM modeling period (e.g., 2005, 2010, .., 2095). Note that in this study, water scarcity conditions are assessed at the grid and basin scales. Note also that the downscaling technique does not allow for population diffusion into currently unpopulated areas, an assumption which may tend to overestimate water scarcity at the grid scale.

Similarly, irrigation water demand is downscaled to a $0.5^{\circ} \times 0.5^{\circ}$ grid using existing global coverage of gridded information of crop areas equipped with irrigation in the year 
Table 2. Comparison of total mean annual runoff in each of the 14 GCAM regions with FAO estimates and two other global hydrologic models (WBM and WGHM).

\begin{tabular}{|c|c|c|c|c|c|c|c|}
\hline & \multirow{2}{*}{ GCAM region name } & \multirow{2}{*}{$\begin{array}{r}\text { Area } \\
1000 \mathrm{ha}\end{array}$} & \multirow{2}{*}{$\begin{array}{r}\text { FAO Estimates } \\
\mathrm{km}^{3} \mathrm{yr}^{-1}\end{array}$} & \multirow{2}{*}{$\begin{array}{r}\text { Fekete et } \\
\text { al. }(2000)(\mathrm{WBM}) \\
\mathrm{km}^{3} \mathrm{yr}^{-1}\end{array}$} & \multirow{2}{*}{$\begin{array}{r}\text { Fekete et } \\
\text { al. (2000) }(\mathrm{WBMc}) \\
\mathrm{km}^{3} \mathrm{yr}^{-1}\end{array}$} & \multirow{2}{*}{$\begin{array}{r}\text { Doll and } \\
\text { Fiedler (2008) } \\
(\mathrm{WGHM}) \\
\mathrm{km}^{3} \mathrm{yr}^{-1}\end{array}$} & \multirow{2}{*}{$\begin{array}{l}\text { This study } \\
\mathrm{km}^{3} \mathrm{yr}^{-1}\end{array}$} \\
\hline & & & & & & & \\
\hline 1 & USA & 964095 & 2825 & 2215 & 2303 & 2382 & 2259 \\
\hline 2 & Canada & 998491 & 2850 & 2067 & 2494 & 2702 & 2751 \\
\hline 3 & Western Europe & 456723 & 2071 & 1564 & 1567 & & 1591 \\
\hline 4 & Japan & 37791 & 430 & 375 & 380 & 367 & 265 \\
\hline 5 & Australia \& NZ & 800977 & 819 & 520 & 545 & 1057 & 1016 \\
\hline 6 & Former Soviet Union & 2230727 & 4731 & 3286 & 4043 & & 4920 \\
\hline 7 & China & 1179691 & 3395 & 2126 & 2608 & 2267 & 2475 \\
\hline 8 & Middle East & 559724 & 184 & 160 & 167 & & 148 \\
\hline 9 & Africa & 3031518 & 3966 & 5518 & 4469 & & 5217 \\
\hline 10 & Latin America & 2051763 & 13575 & 12004 & 12459 & & 10899 \\
\hline 11 & Southeast Asia & 637481 & 6,98 & 5,52 & 5,98 & & 5,06 \\
\hline 12 & Eastern Europe & 116771 & 273 & 302 & 284 & & 333 \\
\hline 13 & Korea & 9,965 & 65 & 55 & 60 & 51 & 47 \\
\hline \multirow[t]{2}{*}{14} & India & 328726 & 1280 & 1264 & 1491 & 1435 & 1399 \\
\hline & Total & 13404443 & 43262 & 37008 & 38568 & 39414 & 38527 \\
\hline
\end{tabular}

2000, as well as the corresponding fraction of coverage of each grid area (both from Siebert et al., 2007) and by crop type (from Portmann et al., 2008). Recall that GCAM computes irrigation water demand at the AEZ scale (151 regions globally). Also, the amounts of new irrigated lands in each crop (AEZ), GCAM region and the corresponding total irrigation volume are known from GCAM for each 5-year interval period between 2005 and 2095. First, starting with the base year estimates, the fraction of irrigated land in each grid is scaled up linearly to account for the additional irrigated lands. When the fraction of irrigated land in a grid cell reaches $100 \%$, the remaining additional irrigated lands are distributed uniformly across the remaining grid cells that are classified as equipped with irrigation. When all grid cells equipped with irrigation are fully irrigated or when irrigation emerges in sub-regional AEZs where no grid cells equipped with irrigation currently exist, irrigated lands are distributed uniformly across all arable lands. Using the density map of the share of irrigated lands and the required irrigation volume, and projecting them into the future, one can estimate the amount of irrigation downscaled to the grid scale.

To downscale livestock water demand, we follow the work of Alcamo et al. (2003a), Flörke and Alcamo (2004), and Wada et al. (2011) in utilizing the gridded global maps of estimated livestock density for six major livestock types (cattle, buffalo, sheep, goats, pigs, and poultry) in year 2000 (Wint and Robinson, 2007). Projecting into the future, the amount of water used is scaled up, assuming the density maps remain static within each GCAM region.

\section{Water scarcity}

Next, we quantify the effect of climate change on water scarcity both globally and in each of the GCAM regions. To estimate water scarcity, we adopt Raskin's definition of water scarcity (Raskin et al., 1997) as the ratio of total water withdrawal (TWW) to total water availability (TWA); i.e., WSI = $\frac{T W W}{T W A}$. This definition of water scarcity is sometimes referred to in the literature as the water resources vulnerability index (WRVI), the withdrawal-to-availability (WTA) ratio, and the criticality ratio (Brown and Matlock, 2011). Following previously suggested thresholds for water scarcity conditions (Falkenmark, 1999; Falkenmark et al., 2007), WSI is divided into four categories: no scarcity (WSI $<0.1$ ) low scarcity $(0.1 \leq \mathrm{WSI}<0.2)$, moderate scarcity $(0.2 \leq \mathrm{WSI}<0.4)$ and severe scarcity (WSI $\geq 0.4$ ). To be consistent with the temporal and spatial scale of GWAM, water demand (withdrawals) results are downscaled from the GCAM output scale (GCAM 14 regions, or 151 AEZ scale) to establish water scarcity for each grid on a mean annual basis.

\section{Policy scenarios}

\subsection{Baseline scenario (no climate policy)}

The baseline scenario reflects a world of 14 billion people, slow technological progress, high energy demands, and no climate policy. More specifically, going from year 2005 to year 2095, population increases from 6.5 billion to 13.7 billion, GDP increases from 30 trillion to 384 trillion 
(USD 1990), and per capita GDP increases from 4607 to 28136 (USD 1990), while energy consumption globally increases from $458 \mathrm{EJ}$ to $2236 \mathrm{EJ}$. This scenario is equivalent to the radiative forcing pathway associated with the SRES A1Fi scenario. The adopted SRES A1Fi scenario reflects an extreme scenario with no mitigation and is somewhat similar to the POP14/MDG- scenario in Hejazi et al. (2013b). To explore the consequences of climate change mitigation policies on water scarcity, we employ the same socioeconomic and technological change assumptions with both a set of policy scenarios and the baseline scenario. This permits isolation of human-induced climate change from population- and income-based effects on water scarcity.

\subsection{Climate change mitigation policy scenarios}

In GCAM, policies designed to mitigate climate change are implemented in regions either as greenhouse gas emissions prices, or as constraints on greenhouse gas emissions, wherein the model solves for the emissions prices necessary to meet the constraints. These emissions policies may price terrestrial carbon dioxide emissions or they may not: Wise et al. (2009) use two canonical carbon tax regimes, (1) a UCT regime which includes all carbon emissions in all sectors (including land use emissions) and all regions of the world; and (2) an FFICT regime which includes only fossil fuel and industrial emissions, but not land-use-related carbon emissions. Under both regimes, the carbon tax rises over time to limit atmospheric $\mathrm{CO}_{2}$ concentrations to a prescribed stabilization level. However, the different types of policies lead to dramatically different outcomes for bioenergy deployment, land use change emissions, and consequently greenhouse gas emissions and climate change. The FFICT case is characterized by very high deployment of bioenergy and associated land use change emissions, which lead to greater emissions and climate change than the UCT case (Wise et al., 2009). However, in all previous results of various climate policy regimes and stabilization levels, water was never included as a potentially limiting resource for bioenergy production or any other activities. In this paper, with the assumption of unlimited non-renewable groundwater and no monetary value attached to water use in GCAM, we do not yet model the feedbacks that result when water demand exceeds the regional water availability. Instead, we simply assess the impact of different target levels of climate change mitigation policies on water scarcity both globally and regionally.

To investigate how different climate change mitigation policies could impact future water scarcity conditions, we have two means to ensure consistency between the selected climate policy and the corresponding GCM forcings used to simulate GWAM. One way is to specify the emission or temperature change target - such as 450 parts per million (ppm) $\mathrm{CO}_{2} \mathrm{e}$ or $2{ }^{\circ} \mathrm{C}$ by the end of the 21 st century - and then to use a GCM run that reflects the same radiative forcings trajectory as in GCAM. This can be a challenge since running a GCM or a set of GCMs to match every policy run can be computationally expensive. One alternative is the use of downscaling techniques to match existing GCM runs to the pathway of interest, an approach that is typically adequate when performing pattern-scaling on temperature but that has known deficiencies when applied to precipitation (Arnell et al., 2011; Cabré et al., 2010). A second alternative is to use existing GCM runs and then force GCAM to reproduce the equivalent radiative forcing trajectory through a particular climate policy. Given that the focus of the study is to explore the implications of climate change mitigation policies on water scarcity, we follow the latter approach in this paper. Thus, we devise climate policies in GCAM that reproduce the four SRES radiative forcings scenarios, where A1Fi is referred to as our baseline scenario (no climate policy), and A2, B2, and B1 are three climate policy scenarios with increasing mitigation stringency of $7.7,5.5$, and $4.2 \mathrm{~W} \mathrm{~m}^{-2}$ in year 2095 , respectively. Figure S5 in the Supplement shows the radiative forcing trajectories based on each of the four SRES emission scenarios (A1Fi, A2, B2, and B1) and each of the UCT and FFICT tax regimes to replicate SRES's emission pathways. Figure S6 in the Supplement shows the corresponding carbon price, $\mathrm{CO} 2$ emission and concentration, and mean global temperature change associated with both the UCT and FFICT tax regimes and all four emission scenarios (A1Fi, A2, B2, and B1) when applicable. Note that the much lower reductions in emissions under the FFICT scenario, as compared to the UCT scenario, is a result of the energy portfolios of each policy regime, where FFICT typically results in a more pronounced contribution of bioenergy to energy than UCT. Also note that the much higher carbon price associated with the more stringent FFICT climate mitigation policies than those observed in current carbon markets results in a significant change in global land use (i.e., biomass expansion). The A1Fi scenario (black solid line) reflects the no-climate policy scenario (baseline).

\section{Results and discussion}

\subsection{Water availability}

To reflect the effect of climate change on water availability, GWAM is simulated over the 21st century with four GCMs (PCM, CGCM2, CSIRO2, and HADCM3) and four emission scenarios (A1Fi, A2, B1, and B2), totaling 16 simulations. The use of multiple GCMs facilitates the quantification of uncertainty associated with GCM results which feed in as input to GWAM. However, results are generally presented by considering their ensemble mean with equal weights. The four emission scenarios represent the baseline scenario and three climate policy scenarios with various levels of GHGs emission reduction targets. Figure 4 shows GWAM's simulations of global annual precipitation, actual evapotranspiration, and runoff from 1901-2100; future values are from the 

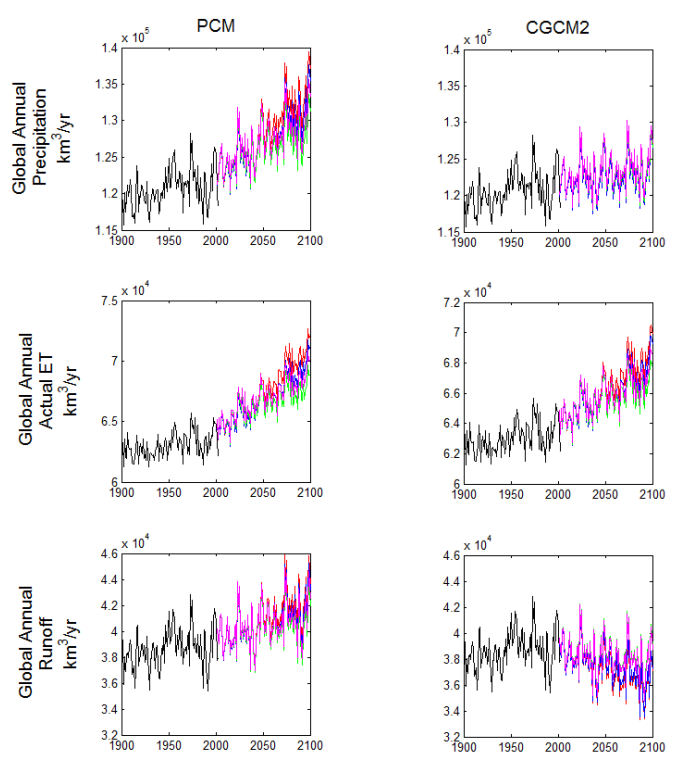
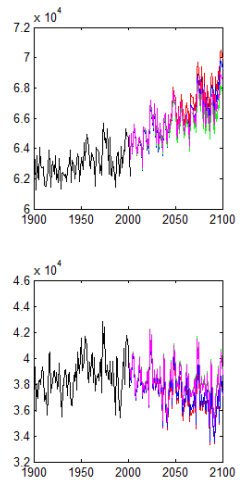
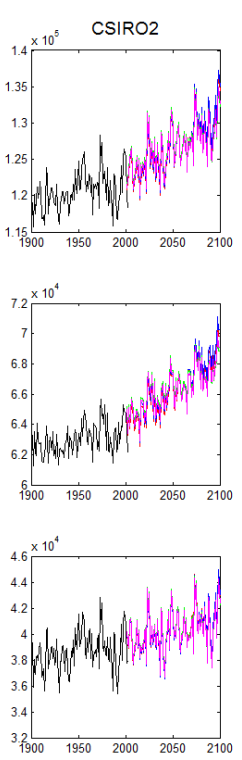
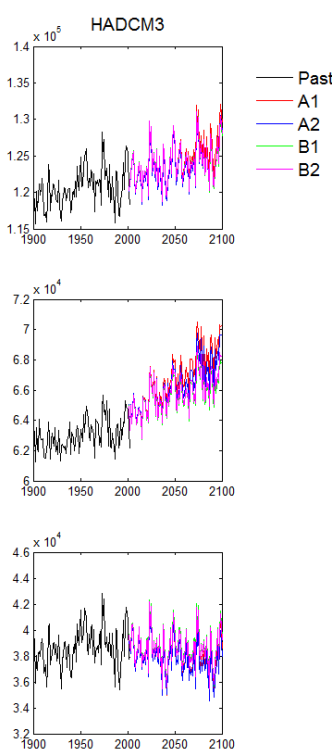

Figure 4. Global annual precipitation, actual evapotranspiration, and runoff from 1901-2100; future values are from four GCMs (PCM, CGCM2, CSIRO2, and HADCM3) and for emission scenarios (A1fi, A2, B1, and B2).

four GCMs and four emission scenarios. Globally, on land, the annual amounts of precipitation and actual evapotranspiration (ET) exhibit an upward trend for all the selected GCMs and emissions. However, only PCM and CSIRO2 exhibit an upward trend in runoff as well, while CGCM2 and HADCM3 show a slight decreasing trend in runoff. To understand the magnitude of potential shifts in water availability due to climate change and the level of variation from using different GCMs and emission scenarios, we compare annual precipitation, actual ET, and runoff estimates in years 2000, 2050, and 2095 (Fig. 5). These time periods are averaged over the 1996-2002, 2046-2055, and 2091-2100 periods, respectively, to filter out the year-to-year variations. Although each of the emission scenarios is associated with a particular warming level, the global amount of water availability does not show a consistent trend with temperature change across the GCM models. The level of uncertainty arising from employing different GCMs and emission scenarios increases over time; i.e., uncertainty is larger in 2095 than in 2050 (Fig. 5). Also, the uncertainty across GCMs is larger than across scenarios. Hence, averaging across GCMs to reflect a particular emission scenario reduces variability and results in a closer match to the historical average runoff, although spatial variations remain high in many cases. Figure 6 shows the difference in ensemble mean runoff at the grid scale between years 2095 and 2000 for each of the of four emission scenarios. Although globally humans may end up with more available water through runoff globally, when looking at the spatial distribution of gains and losses in freshwater, there are clear winners (Canada, northern Europe, Russia, India, and northern China) and losers (e.g., most of South America, eastern half of the US, rest of Europe, the Middle East, and
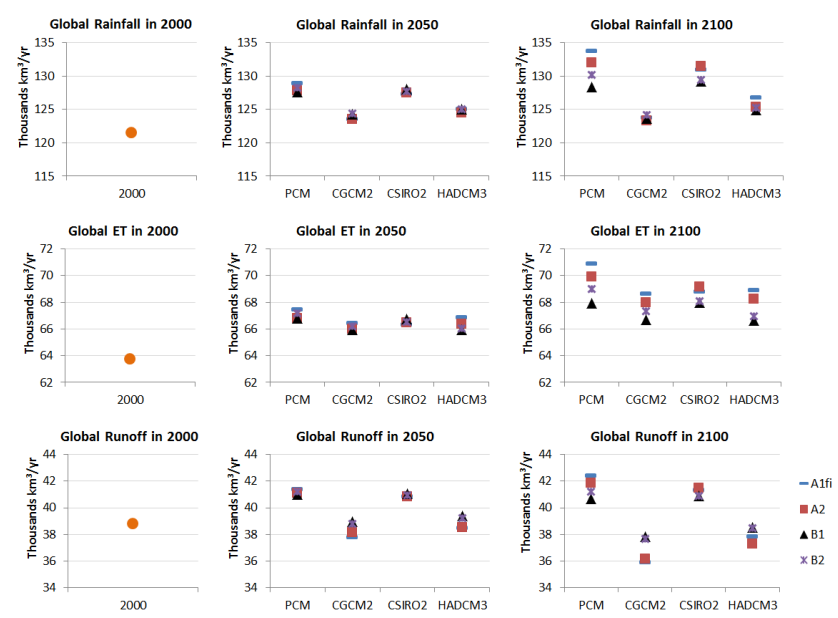

Figure 5. Comparison of annual precipitation, actual ET, and runoff estimates across GCMs and emission scenarios in years 2000, 2050, and 2095; uncertainty across GCMs is larger than scenarios, and the uncertainty level increases with time, in other words, uncertainty is larger in 2100 than 2050.

Southeast Asia and Australia). Those regional patterns are consistent across all four emission scenarios, and somewhat similar to the finding of Arnell (2004), who found a reduction in runoff in much of Europe, the Middle East, southern Africa, North America and most of South America, and increasing runoff in high-latitude North America and Siberia, eastern Africa, parts of arid Saharan Africa and Australia, and South and East Asia. 


\subsection{Water demands}

Global water demands (withdrawals and consumption) have been produced based on a baseline scenario and six climate policy scenarios (UCT7.7, UCT5.5, UCT4.2, FFICT7.7, FFICT5.5, FFICT4.2). In all six policy scenarios, the global water withdrawals and consumption increase from the base-year level to the end of the century. Global water withdrawals increase in the baseline scenario from 3710 to $9062 \mathrm{~km}^{3}$ year $^{-1}$ by 2050 and $13318 \mathrm{~km}^{3}$ year $^{-1}$ by 2095. Global water consumptive use increases in the baseline scenario from 1215 to $3177 \mathrm{~km}^{3}$ year $^{-1}$ by 2050 and $4558 \mathrm{~km}^{3} \mathrm{year}^{-1}$ by 2095 . Across all six climate policy scenarios, global water withdrawals range from $8843 \mathrm{~km}^{3}$ year ${ }^{-1}$ in UCT4.2 to $9276 \mathrm{~km}^{3}$ year $^{-1}$ in FFICT4. 2 in 2050, and from $12533 \mathrm{~km}^{3}$ year $^{-1}$ in UCT4.2 to $25357 \mathrm{~km}^{3}$ year $^{-1}$ in FFICT4.2 in 2095. Similarly, global water consumptive use ranges from $3142 \mathrm{~km}^{3}$ year $^{-1}$ in UCT4. 2 to $3350 \mathrm{~km}^{3} \mathrm{year}^{-1}$ in FFICT4.2 in 2050 , and from $4364 \mathrm{~km}^{3}$ year ${ }^{-1}$ in UCT4.2 to $8719 \mathrm{~km}^{3}$ year $^{-1}$ in FFICT4.2 in 2095. In the remaining sections, the focus is on the quantity of water withdrawals even though both withdrawals, and consumption are provided by GCAM.

Driven by increasing stringency in climate change mitigation policies and maintaining identical socioeconomic and technological assumptions across the six policy scenarios, Figure 7 shows the global water withdrawals for the baseline and the six policy scenarios in comparison to historical estimates and forecasts. Gleick (2003) states that pre-1980 estimates of future projections tended to overestimate future global water withdrawals; however, our detailed, activity-based assessment of future water withdrawals generally yields higher future water withdrawals than those produced by recent studies (Alcamo et al., 2003b, 2007; Shen et al., 2008), mainly due to high population projection associated with the baseline scenario and the greater expansion of irrigated area in this study. Regardless, both previous studies and our scenarios indicate that water demands are likely to increase globally in this century, even in the most stringent future mitigation scenarios.

Figure 8 shows GCAM's estimates of global water demands (withdrawals) for the baseline scenario (no climate policy) and the six climate change mitigation policy scenarios for each of the water demand sectors, i.e., irrigation (biomass, crops), livestock, domestic, primary energy, electricity, and manufacturing. The variation in water demands by sector depends on the interdependence of each sector on the implications of the differing climate policy tax regimes (UCT vs. FFICT) and climate mitigations targets. For example, biomass water withdrawals increase from zero in 2005 up to a range of $438-530 \mathrm{~km}^{3}$ year $^{-1}$ in 2095 for the three UCT scenarios, and to a range of $1782-13212 \mathrm{~km}^{3}$ year $^{-1}$ in 2095 for the three FFICT scenarios. The large differences in the ranges are attributed to the dramatic increase of biomass production under the energy portfolio of the FFICT scenar- ios in meeting the climate policy targets. In contrast, municipal water demand shows no sensitivity to climate policy and all six policy scenarios are identical to the baseline scenarios, i.e., from $466 \mathrm{~km}^{3} \mathrm{year}^{-1}$ in 2005 to $1392 \mathrm{~km}^{3}$ year ${ }^{-1}$ in 2095; the effects of elevated temperatures on water demands are not accounted for in this study.

Total crop irrigation (excluding biomass) water withdrawals increase from $2464 \mathrm{~km}^{3}$ year $^{-1}$ in 2005 to 9053-9686 km $\mathrm{kear}^{-1}$ (UCT scenarios), and to 9078$9315 \mathrm{~km}^{3}$ year $^{-1}$ (FFICT scenarios) in 2095. Livestock demands reflect the population- and income-driven growth in meat and dairy demands combined with a relatively minor price effect, increasing livestock water withdrawals from $18 \mathrm{~km}^{3}$ year $^{-1}$ in 2005 to $39-54 \mathrm{~km}^{3}$ year $^{-1}$ (UCT scenarios), and to $58-62 \mathrm{~km}^{3}$ year $^{-1}$ (FFICT scenarios) in 2095. Domestic water withdrawals increase from $466 \mathrm{~km}^{3}$ year $^{-1}$ (196 $\mathrm{Lperson}^{-1} \mathrm{day}^{-1}$ ) in 2005 to $1392 \mathrm{~km}^{3}$ year $^{-1}$ $\left(279 \mathrm{~L} \mathrm{person}^{-1} \mathrm{day}^{-1}\right.$ ) in 2095. Primary energy and electricity water demands could increase or decrease depending on the prevailing climate policy scenarios. Primary energy water withdrawals may increase (or decrease) from $19 \mathrm{~km}^{3}$ year ${ }^{-1}$ in 2005 to $34 \mathrm{~km}^{3}$ year ${ }^{-1}$ in the baseline scenario due to higher coal and oil demands (or to $7 \mathrm{~km}^{3}$ year $^{-1}$ in FFICT4.2 due to the shift from more water-intensive primary energy sources (e.g., crude oil) to less water-intensive options such as mining production and natural gas)) in 2095, and electricity water withdrawals may increase (or decrease) from $535 \mathrm{~km}^{3}$ year $^{-1}$ in 2005 to $755 \mathrm{~km}^{3}$ year $^{-1}$ in the UCT4. 2 scenario (or to $466 \mathrm{~km}^{3}$ year ${ }^{-1}$ in FFICT7.7) in 2095. The large drop in electric-sector water withdrawals around mid-century arises due to the assumed long-term phase-out of once-through flow cooling systems, which are characterized by high water withdrawal rates, in favor of lower-withdrawal wet towers, cooling ponds, and dry cooling systems. Manufacturing water withdrawals increase from $209 \mathrm{~km}^{3}$ year $^{-1}$ in 2005 to $749-934 \mathrm{~km}^{3}$ year $^{-1}$ (UCT scenarios), and to $820-895 \mathrm{~km}^{3}$ year $^{-1}$ (FFICT scenarios) in 2095. In total, global water withdrawals increase from $3710 \mathrm{~km}^{3}$ year $^{-1}$ in 2005 to $12533-13010 \mathrm{~km}^{3}$ year $^{-1}$ (UCT scenarios), and to $13935-25357 \mathrm{~km}^{3}$ year $^{-1}$ (FFICT scenarios) in 2095, thus, suggesting worsening water scarcity in the future.

Figure 9 shows the re lative change in total water withdrawals for each of the demand sectors between the baseline scenario and each of the six climate policy scenarios. The effect of climate change mitigation policies on the estimated water withdrawals varies across water demand sectors. When comparing the results of the policy scenarios to the baseline scenario, the projected changes in biomass water demand range from -53 to $100 \%$ in 2050 and -59 to $1317 \%$ in 2095. With more stringent FFICT policies (i.e., lower mitigation targets, e.g., $4.2 \mathrm{~W} \mathrm{~m}^{-2}$ ), biomass water demand increases substantially, and it generally decreases with more stringent UCT policies. As compared to biomass, the sensitivity of crop water withdrawals to climate policy is much 

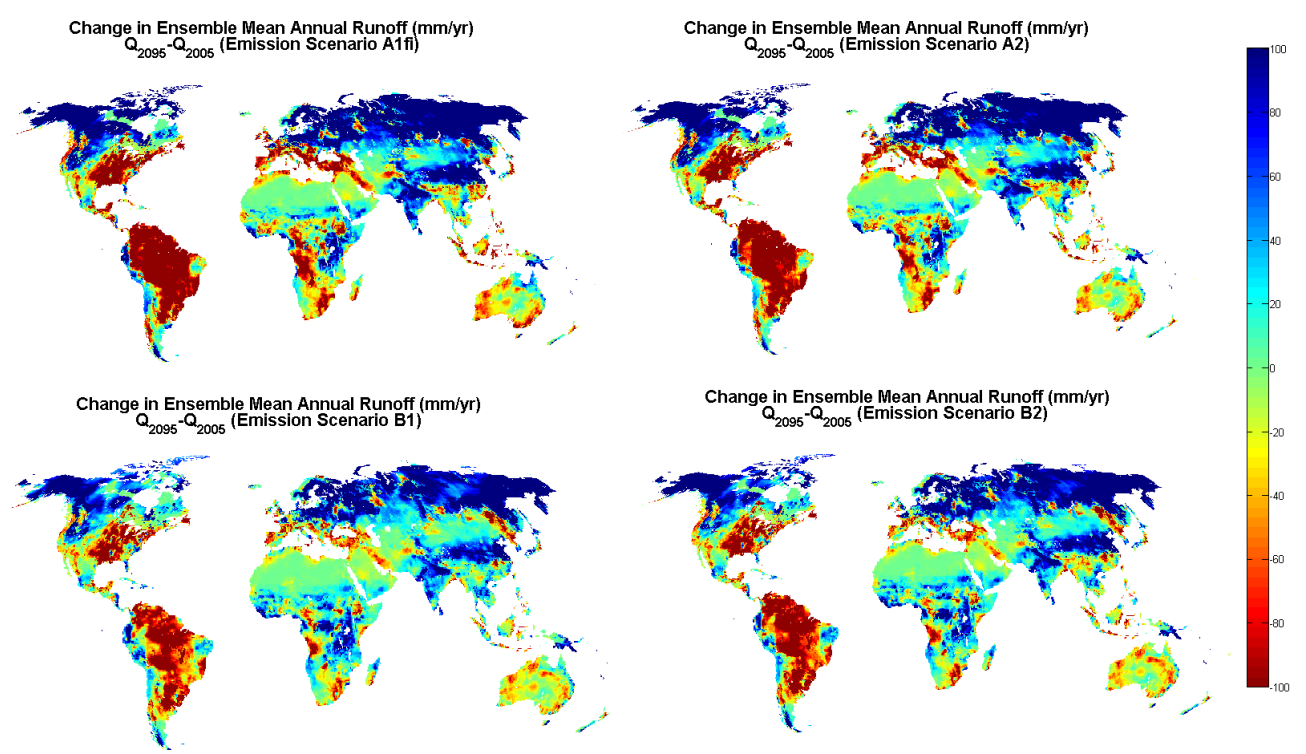

Figure 6. Change in ensemble mean annual runoff between 2095 and 2005 for each of the four emission scenarios (A1fi, A2, B1, and B2).

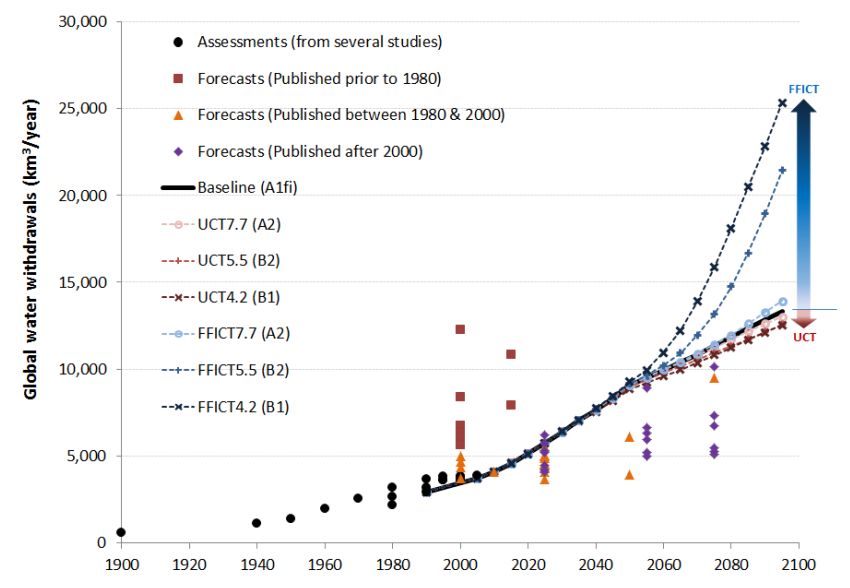

Figure 7. Global water withdrawals for the baseline and the six policy scenarios in comparison to literature estimates of historical water use and other studies; sources: Gleick (2003) (and references therein), Falkenmark and Rockström (2000), Alcamo et al. (2003a, b, 2007), Shiklomanov and Rodda (2003), Shen et al. (2008), Wada et al. (2011), and AQUASTAT (2011).

less evident and only ranges from 0 to $4 \%$ in 2050 and -3 to $4 \%$ in 2095 . The effect of climate policy on livestock water withdrawals (as compared to the baseline scenario) ranges from 0 to $14 \%$ in 2050 and 0 to $38 \%$ in 2095, with policy scenarios projecting lower demands, and with larger reductions associated with more stringent policies; i.e., the largest drop in livestock water demands are under the UCT4.2 and FFICT4.2 scenarios. More stringent climate policies also cause greater reductions in primary energy water demands, however, with FFICT scenarios projecting lower demands than their equivalent UCT scenarios. The effect of climate
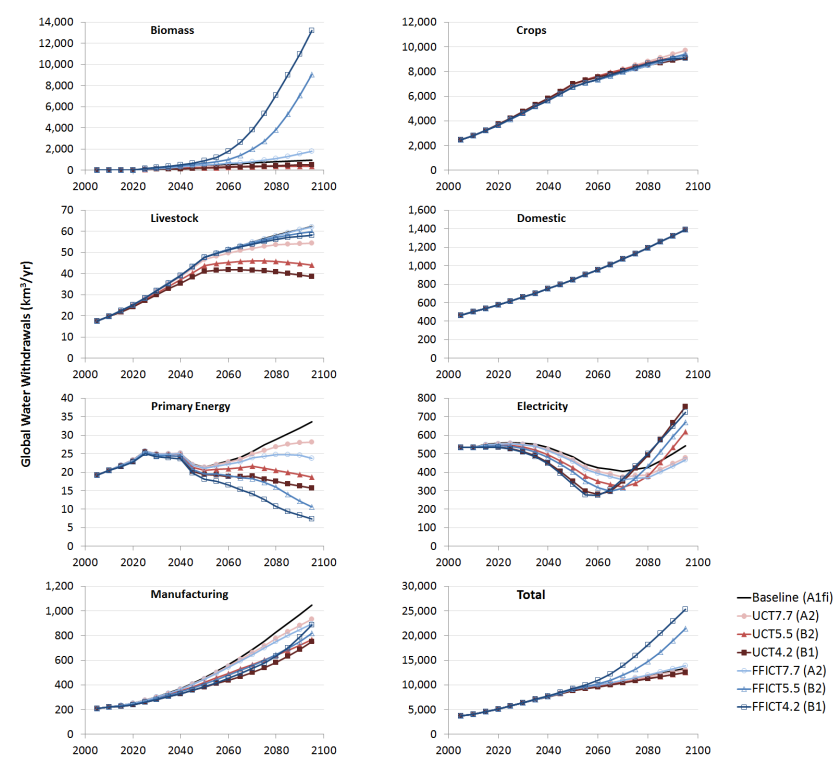

Figure 8. GCAM's estimates of global water demands (withdrawals) for the baseline (A1fi) scenario (no climate policy) and the six climate change mitigation policy scenarios (UCT7.7 (A2), UCT5.5 (B2), UCT4.2 (B1), FFICT7.7 (A2), FFICT5.5 (B2), FFICT4.2 (B1)) for each of the water demand sectors.

policy on electricity and manufacturing water withdrawals (as compared to the baseline scenario) ranges from -31 to $-3 \%$ in 2050 and -14 to $39 \%$ in 2095 , and from -16 to $-1 \%$ in 2050 and -29 to $-11 \%$ in 2095 , respectively. In total, the attributed change in global water withdrawals from the policy scenarios range from -2 to $2 \%$ in 2050 and -6 to $90 \%$ in 2095 . Thus, depending on the adopted policy type and target, climate change mitigation policies could either 


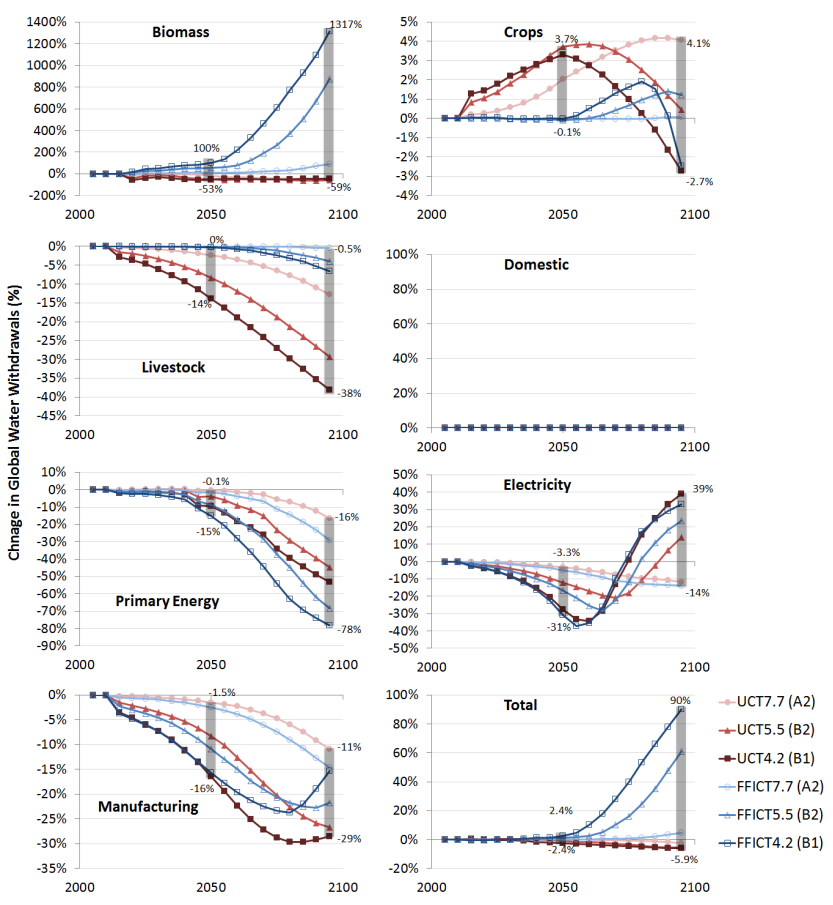

Figure 9. Deviations in GCAM's estimates of global water withdrawals from the baseline (A1fi) scenario (no climate policy) for each of the six climate change mitigation policy scenarios (UCT7.7 (A2), UCT5.5 (B2), UCT4.2 (B1), FFICT7.7 (A2), FFICT5.5 (B2), FFICT4.2 (B1)) for each of the water demand sectors.

increase or decrease future global water withdrawals, an effect that becomes increasingly apparent, especially during the second half of the century.

Figure 10 shows the distribution of global water withdrawals by sector for the baseline scenario and each of the climate change mitigation policies. Three main observations include that (1) crop water demands remain the dominant source of water withdrawals over the whole century with the exception of the FFICT4.2 scenario, (2) the share of water withdrawals for electricity generations diminishes over time, and (3) the share biomass water withdrawals start to emerge strongly with the more stringent FFICT scenarios (e.g., FFICT5.5 and FFICT4.2). However, some of those changes prevail under the baseline scenario as well. The decreasing share for electricity water withdrawal is due to the assumed long-term phase-out of once-through flow cooling systems, and occurs in the baseline scenario. Figure S7 in the Supplement shows pie chart distributions of global water withdrawals by sector for the baseline scenario in years 2005 and 2095, and each of the climate change mitigation policies in year 2095. Similar to year 2005, all distributions show agriculture as the dominant source of withdrawals followed by industry, and then domestic use. However, with the more stringent policies, the share of industrial water demands slightly diminishes and becomes comparable to the domestic share for both UCT and FFICT scenarios. The pro-

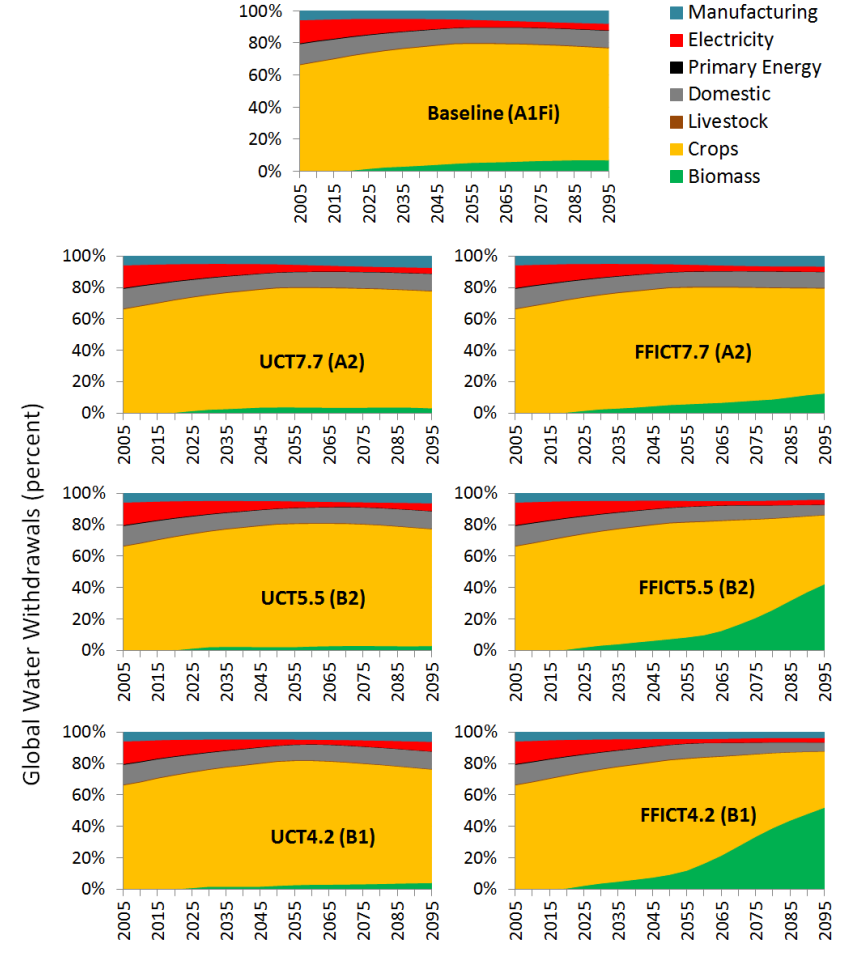

Figure 10. GCAM's distribution of global water demands (withdrawals) by demand sector for the baseline scenario (no climate policy) and the six climate change mitigation policy scenarios.

portion of biomass share increases most dramatically under the more stringent FFICT scenarios, making it an important competitor for future water demands and reducing the shares attributed to other sectors, especially other crops.

\subsection{Water scarcity}

With projections of gridded water demand and supply results, global maps of water scarcity are produced for the years 2005 and 2095. For a detailed set of results showing the individual gridded water demands and gridded runoff, and the resulting water scarcity under the reference scenario, see Figs. S7-14 in the Supplement. Figure 11 shows the gridded global maps of water scarcity for the baseline and the six policy scenarios in the year 2095. Recall that a water scarcity index value of 0.4 or higher (WSI $\geq 0.4$ ) denotes severe scarcity, $(0.2 \leq \mathrm{WSI}<0.4)$ denotes moderate scarcity, $(0.1 \leq \mathrm{WSI}<0.2)$ denotes low scarcity, and $(\mathrm{WSI}<0.1)$ denotes no scarcity, or abundant water resources as compared with demands. Generally, the gridded global water scarcity map is spatially consistent across all scenarios, with regions in eastern China, northern India, and the Middle East projected to experience extreme scarcity conditions in 2095 . Since it is not clearly apparent from Fig. 11 how water scarcity has changed spatially over time or due to each of the climate policies, Fig. 12 shows the change in water scarcity 


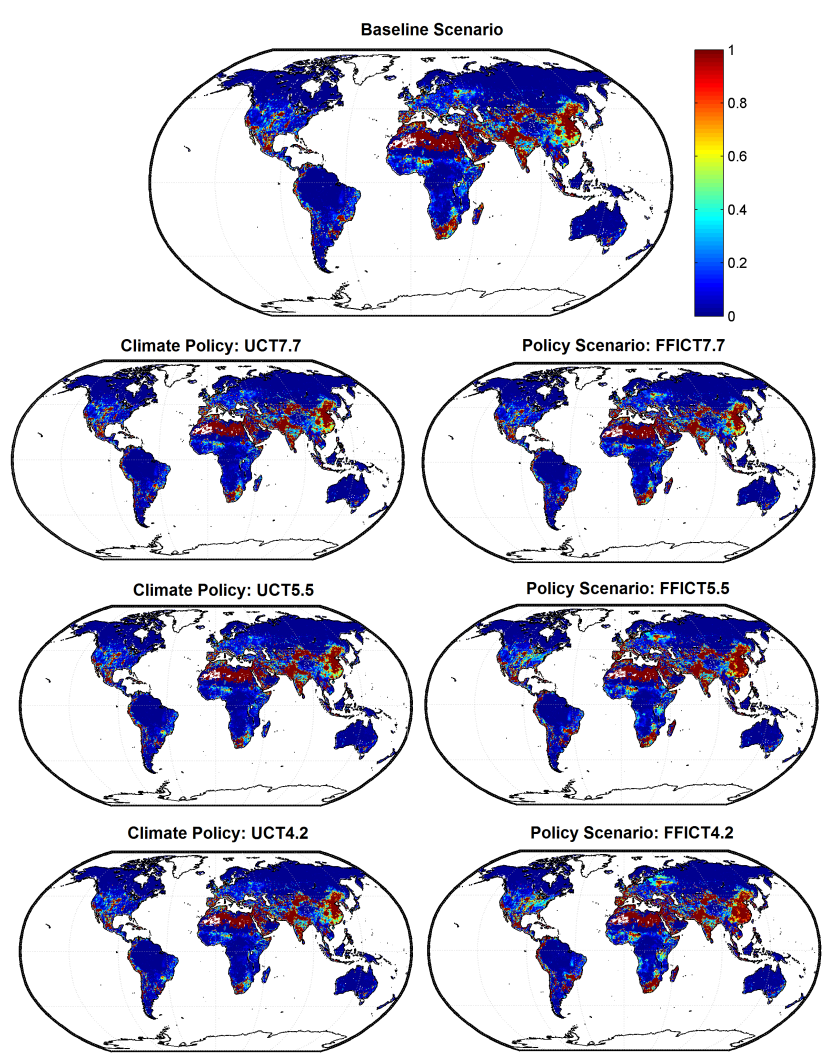

Figure 11. GCAM's downscaled water scarcity results in the year 2095 under each of the climate policies.

index between 2095 and 2005, and Fig. 13 shows the departure of each of the six policy scenarios from the baseline scenario in year 2095.

Generally, in 2095 more regions experience similar or elevated water scarcity conditions (Fig. 12). More specifically, regions that are experiencing some level of scarcity are projected to experience even more scarcity primarily due to mounting demands and changes in water availability in various regions. The largest increases in scarcity over the $21 \mathrm{st}$ century include regions in eastern China, India, western Europe, and the Middle East. Some of that change is attributed to the large increase in population and income effect in these regions under the adopted socioeconomic assumptions for all the scenarios. Comparing across policies, Fig. 13 shows that the policy-caused anomaly from the baseline scenario (no climate policy) in year 2095 is spatially heterogeneous and depends on both the policy type (UCT vs. FFICT) and stringency level (e.g., 7.7, 5.5, and $4.2 \mathrm{~W} \mathrm{~m}^{-2}$ ). As shown in Fig. 9, compared to the baseline scenario, the global water demand could decrease by up to $5.9 \%$ in 2095 under the most stringent UCT policy (UCT4.2), or increase by up to $90 \%$ under the most stringent FFICT policy (FFICT4.2). Thus, when distributing that global result spatially (Fig. 13), the effects of climate policy propagate differently in different regions due to land use and energy choices in these
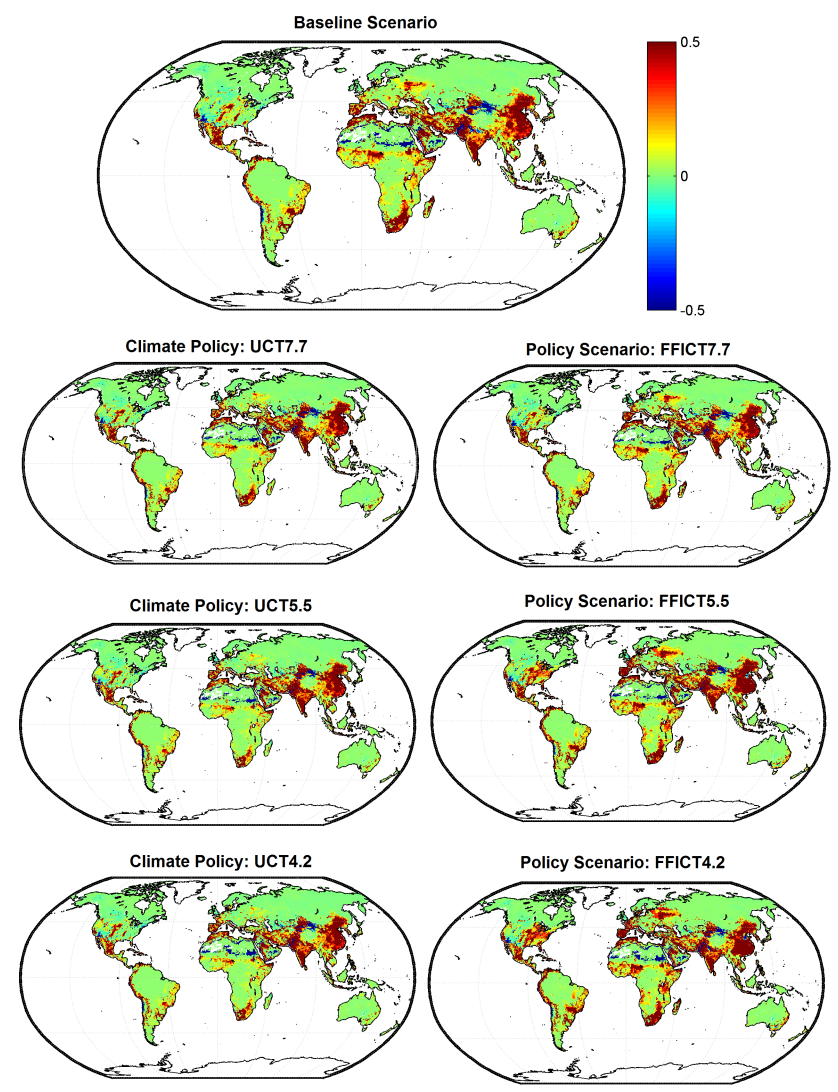

Figure 12. Changes in water scarcity conditions from 2005 to 2095 reflecting different climate change mitigation policies; positive values (red) denote increased scarcity conditions in 2095 as compared to 2005 .
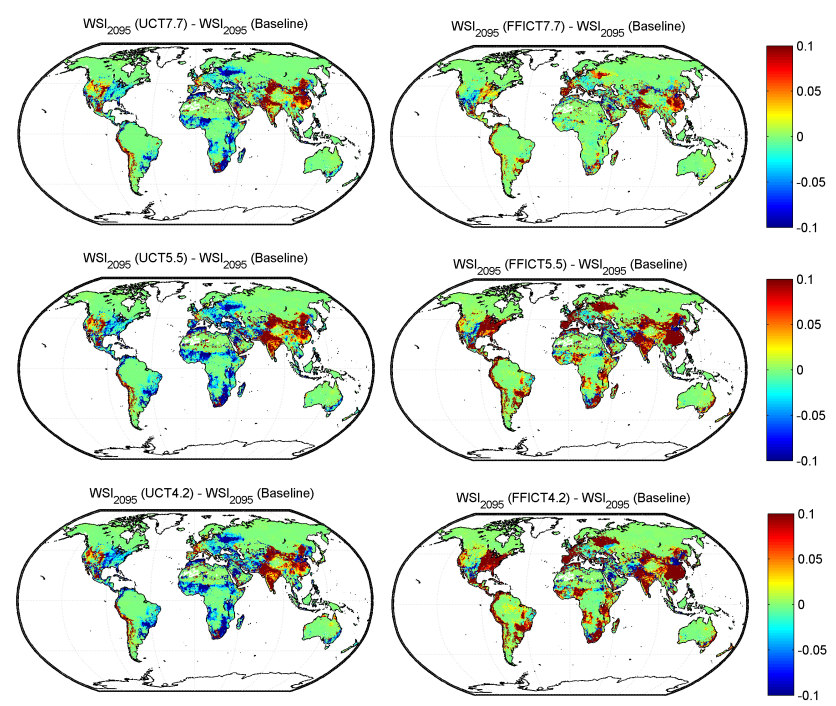

Figure 13. The effect of climate change mitigation policies on the magnitude of the WSI; all six policy scenarios are compared to the baseline scenario (A1fi) in 2095. 
regions governing water demands. Also the spatial variation is confounded by regional differences in the impact of climate change on water availability. Thus, there are regions that are projected to see more scarcity, even though globally there will be less water demanded than the baseline scenario under the UCT scenarios. For example, regions in central Asia and the western United States will experience more scarcity due to UCT climate policies, while other regions will experience less scarcity, such as Africa, eastern Europe, and the eastern United States. The reasons are complex and likely dependent on several interdependent factors, such as energy and land use choices that are spatially heterogeneous (e.g., policy-induced shifts in favor of a particular crop that is grown in particular regions, causing higher water demands), the spatial heterogeneity of climate change effects on regional hydrology and water availability, changes in technological progress in different regions, variations in socioeconomic drivers, and so on. When the results are varied within a GCAM region, such as the United States, then the likely factor is variability in the agricultural sector water demands, since those are modeled at the AEZ scale (e.g., there are 10 AEZs in the United States) and changes in water availability (e.g., GWAM's representation includes many grid cells in the United States). Under the FFICT scenarios, the spatial coverage is more homogeneous mainly because water demands for biomass production dominate these scenarios. Under the FFICT climate policy scenarios as compared to the baseline scenario, most regions will experience some increase of water scarcity. However, noting the scale difference between Figs. 12 and 13, it is apparent that projected increases in water scarcity between 2095 and 2005 are much larger than the differences between policy and no policy scenarios.

\subsection{Global population under scarcity (baseline scenario)}

Aggregating water scarcity globally under the baseline scenario (no climate policy), Fig. 14a and b show the likely shifts to the cumulative distribution function of the fraction of the global population living under different levels of scarcity (WSI) at the grid and basin scales, respectively. The thin lines reflect the uncertainty corresponding to any single climate model of the four GCMs instead of the ensemble mean of total annual water availability. Global populations living under severe water stress conditions at the grid scale (basin scale) increase from $42 \%(29 \%)$ in year 2005 to $56 \%(56 \%)$ and $66 \%(64 \%)$ in years 2050 , and 2095 , respectively; i.e., more than half of the world population will live under severe scarcity conditions in year 2050. Table 4 summarizes the proportion of global population living under each water scarcity category. When compared to previous estimates from the literature (Wada et al., 2011) (and references therein) for current population experiencing scarcity conditions (1995-2000), our estimates in year 2005 fall within the
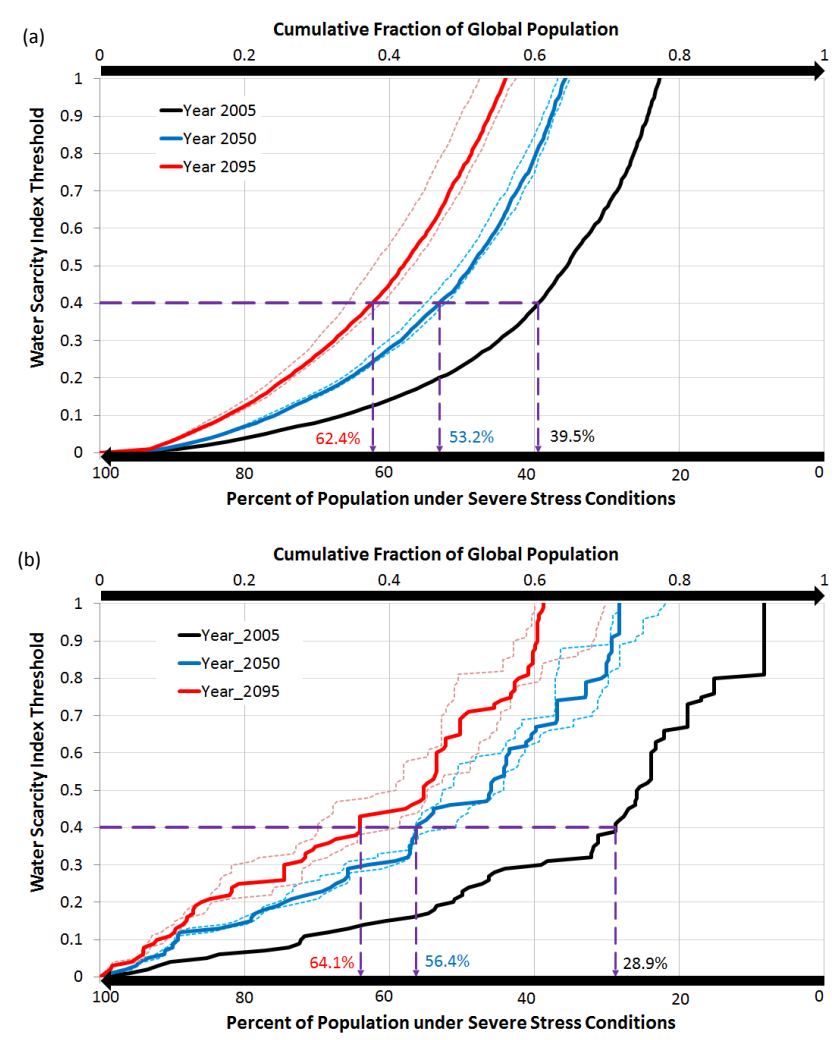

Figure 14. Shifts to the cumulative probability density function of the fraction of the global population living under different levels of scarcity (WSI); water scarcity is estimated at the grid (a) and basin (b) scales; the thin lines reflect the uncertainty corresponding to the any one of the four GCMs instead of the ensemble mean; global populations living under severe water stress conditions increase from $40 \%(29 \%)$ in year 2005 to $53 \%(56 \%)$ and $62 \%$ $(64 \%)$ in years 2050 , and 2095 , respectively.

documented range. The range of results signifies the wide level of uncertainty in such estimates. Uncertainty could arise from the method of estimating total water availability, to water demand projections, to spatial and temporal scale of water scarcity calculations, and to how demands are downscaled to the appropriate scale.

Figure 15 shows the distributions of global populations facing each of the four levels of water scarcity. Note that WSI values are computed at the grid and basin scales and then aggregated to the global scales. Regardless of the adopted scale of calculating WSI and the associated populations, both panels in Fig. 15 show an increasing proportion of global population living under severe water stress under both the ensemble mean and all individual GCMs. Figure 16a and $\mathrm{b}$ show the evolution of the fraction of the global population living under severe water stress (WSI $\geq 0.4$ ) when computing WSI at the grid and basin scales, respectively. The dashed lines represent the result associated with an individual GCM instead of the ensemble mean. The grid scale results (in comparison to basin scale results) tend to overestimate the water scarcity 
Table 3. Estimates of models' departure (RMSE) from FAO (2010) estimates at the country scale (only countries for which all four models have values are used to estimate the RMSE values) and the GCAM scale; units are in $\mathrm{km}^{3} \mathrm{yr}^{-1}$.

\begin{tabular}{lrrrr}
\hline $\begin{array}{l}\text { Deviation from } \\
\text { FAO (2010) estimates }\end{array}$ & $\begin{array}{r}\text { WBM Fekete } \\
\text { et al. (2000) }\end{array}$ & $\begin{array}{r}\text { WBMc Fekete } \\
\text { et al. (2000) }\end{array}$ & $\begin{array}{r}\text { WGHM* Doll } \\
\text { and Fiedler (2008) }\end{array}$ & This study \\
\hline Country scale & 212 & 187 & 118 & 168 \\
GCAM regional scale & 905 & 572 & - & 956 \\
\hline
\end{tabular}

Table 4. Fraction of global population living under each water scarcity category, and under different climate mitigation policies and tax regimes; scarcity is calculated at the grid scale (basin scale).

\begin{tabular}{rlrrrrr}
\hline $\begin{array}{r}\text { Time } \\
\text { period }\end{array}$ & $\begin{array}{l}\text { Tax } \\
\text { regime }\end{array}$ & $\begin{array}{r}\text { RF in 2095 } \\
\left(\mathrm{W} \mathrm{m}^{-2}\right)\end{array}$ & $\begin{array}{r}\text { No stress } \\
{[\mathrm{WSI}<0.1]}\end{array}$ & $\begin{array}{r}\text { Low stress } \\
{[0.2 \leq \mathrm{WSI}<0.4]}\end{array}$ & $\begin{array}{r}\text { Moderate stress } \\
{[0.2 \leq \mathrm{WS}<0.4]}\end{array}$ & $\begin{array}{r}\text { Severe stress } \\
{[\mathrm{WSI} \geq 0.4]}\end{array}$ \\
\hline \multirow{2}{*}{2005} & & & $0.295(0.277)$ & $0.141(0.211)$ & $0.145(0.224)$ & $0.419(0.289)$ \\
\hline & BAU & 8.8 & $0.194(0.108)$ & $0.110(0.148)$ & $0.131(0.180)$ & $0.565(0.564)$ \\
& UCT & 7.7 & $0.200(0.161)$ & $0.113(0.116)$ & $0.128(0.167)$ & $0.560(0.556)$ \\
& UCT & 5.5 & $0.217(0.183)$ & $0.111(0.104)$ & $0.129(0.199)$ & $0.543(0.514)$ \\
2050 & UCT & 4.2 & $0.227(0.183)$ & $0.113(0.123)$ & $0.126(0.189)$ & $0.534(0.505)$ \\
& FFICT & 7.7 & $0.194(0.108)$ & $0.110(0.148)$ & $0.131(0.183)$ & $0.566(0.561)$ \\
& FFICT & 5.5 & $0.198(0.101)$ & $0.112(0.155)$ & $0.130(0.185)$ & $0.561(0.559)$ \\
& FFICT & 4.2 & $0.200(0.101)$ & $0.113(0.144)$ & $0.129(0.191)$ & $0.558(0.565)$ \\
\hline & BAU & 8.8 & $0.123(0.079)$ & $0.089(0.061)$ & $0.125(0.219)$ & $0.664(0.641)$ \\
& UCT & 7.7 & $0.140(0.101)$ & $0.093(0.140)$ & $0.123(0.143)$ & $0.644(0.616)$ \\
& UCT & 5.5 & $0.150(0.121)$ & $0.092(0.140)$ & $0.119(0.167)$ & $0.639(0.573)$ \\
2095 & UCT & 4.2 & $0.146(0.127)$ & $0.092(0.123)$ & $0.122(0.138)$ & $0.640(0.612)$ \\
& FFICT & 7.7 & $0.127(0.074)$ & $0.087(0.062)$ & $0.121(0.183)$ & $0.666(0.681)$ \\
& FFICT & 5.5 & $0.114(0.064)$ & $0.074(0.045)$ & $0.104(0.133)$ & $0.708(0.758)$ \\
& FFICT & 4.2 & $0.109(0.056)$ & $0.070(0.047)$ & $0.101(0.127)$ & $0.720(0.770)$ \\
\hline Range of literature $(1995-2000)$ & $0.21-0.62$ & $0.07-0.37$ & $0.07-0.27$ & $0.08-0.48$ \\
\hline
\end{tabular}

condition at the beginning of the century, but the difference between the grid and basin scale results diminishes towards the end of the century; i.e., the fraction of the global population living under severe water stress ranges between 60 and $70 \%$ by the end of the 21 st century (Fig. 16).

\subsection{Global population under scarcity (climate policy scenarios)}

Aggregating water scarcity globally under the various climate change mitigation policies and comparing it to the baseline scenario, Fig. 17a and $b$ show the likely shifts to the cumulative density function (cdf) of the fraction of the global population living under different levels of scarcity (WSI) at the grid and basin scales, respectively. Comparing between 2095 and 2005 under the baseline scenario, the cdf curve shifts to the left, denoting exacerbated water scarcity conditions and a higher fraction of global population living under water stress. The thin lines reflect the uncertainty corresponding to any single climate model of the four GCMs instead of the ensemble mean of total annual water availability. The cdf in 2095 shifts slightly to the right under the UCT4.2 scenario and much further to the left under the FFICT4.2 scenarios. Thus, globally on average, UCT climate policies moderately alleviate water scarcity conditions and FFICT climate policies induce the opposite and more pronounced effect on water scarcity.

Figure 18 shows the fraction of the global population living in grid cells (Fig. 18a) or basins (Fig. 18b) that are classified as severe scarcity conditions (WSI $\geq 0.4$ ) for the baseline scenario and the six policy scenarios in years 2095. The dashed bars reflect the level of uncertainty if a single GCM is used instead of the ensemble of four GCMs to compute water availability for each grid. Global populations living in grid cells (basins) under severe water stress conditions in year 2095 drop from $66 \%(64 \%)$ in the baseline scenario to about $64 \%$ (57\%) under the various UCT scenarios, with no observable direction of change due to more stringent UCT climate policies. In contrast, the percentage of the global population living under severe water stress conditions in 2095 increases with more stringent FFICT policies, rising from $66 \%$ (64\%) under the baseline scenario to $72 \%(77 \%)$ under the FFICT4.2 scenario. Table 4 summarizes the proportion of global population living under each water scarcity 

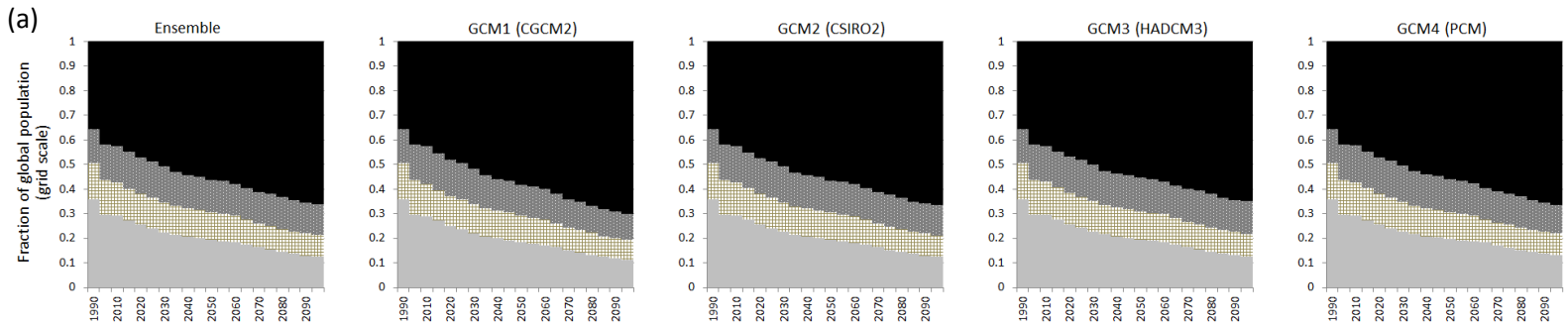

- Severe Stress Moderate Stress \#Low Stress wo Stress
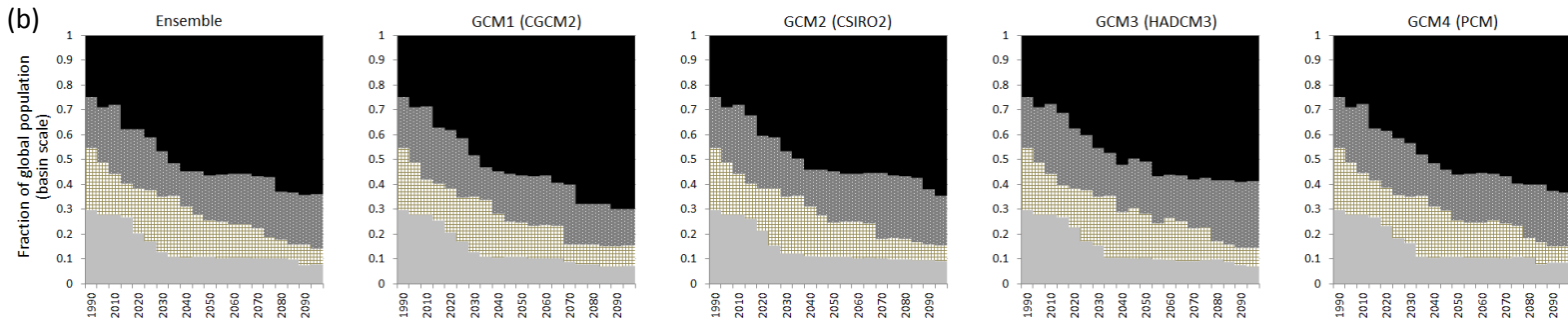

Severe Stress * Moderate Stress \# Low Stress = No Stress

Figure 15. Distributions of global populations facing each of the four levels of water scarcity conditions: severe stress (WSI $\geq 0.4$ ), moderate stress $(0.2 \leq \mathrm{WSI}<0.4)$, low stress $(0.1 \leq \mathrm{WSI}<0.2)$, and no stress (WSI $<0.1)$; WSI values are computed at the grid (top panel) and basin (bottom panel) scales and then the shares of populations are aggregated to the global scale.
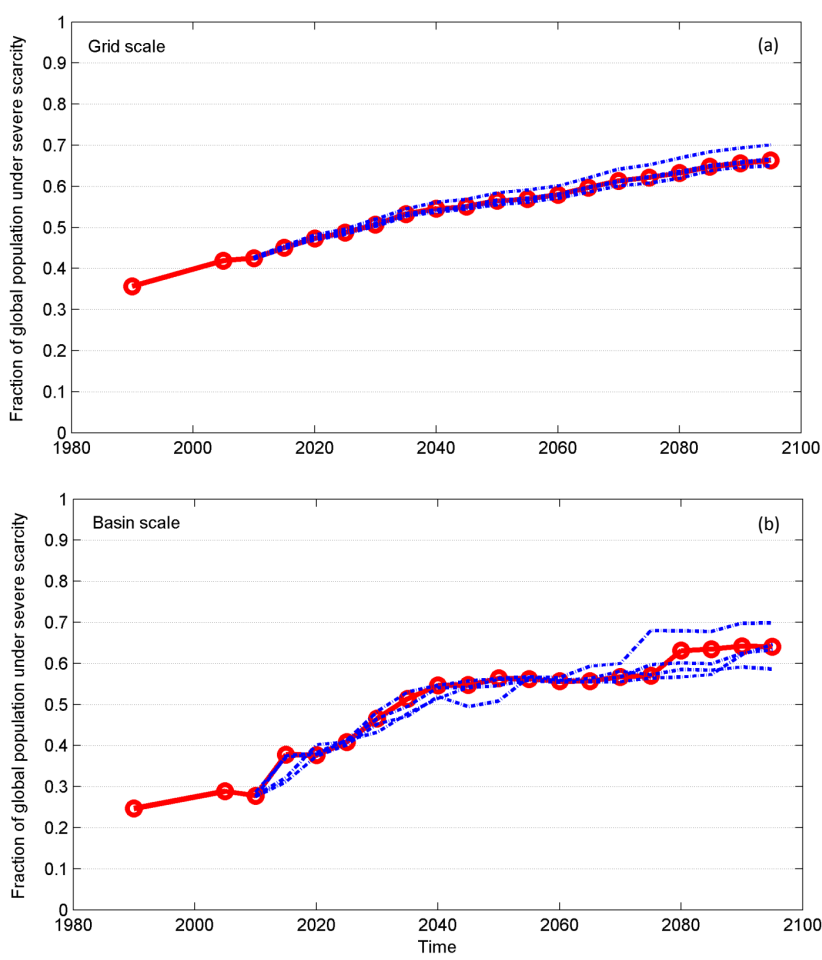

Figure 16. Estimated percentage of global population living under severe water scarcity conditions (WSI $\geq 0.4$ ) at the grid (top panel) and basin (bottom panel) scales.

category for the baseline scenarios and the six policy scenarios in years 2050 and 2095.

When compared to previous water scarcity estimates from the literature for current population experiencing scarcity

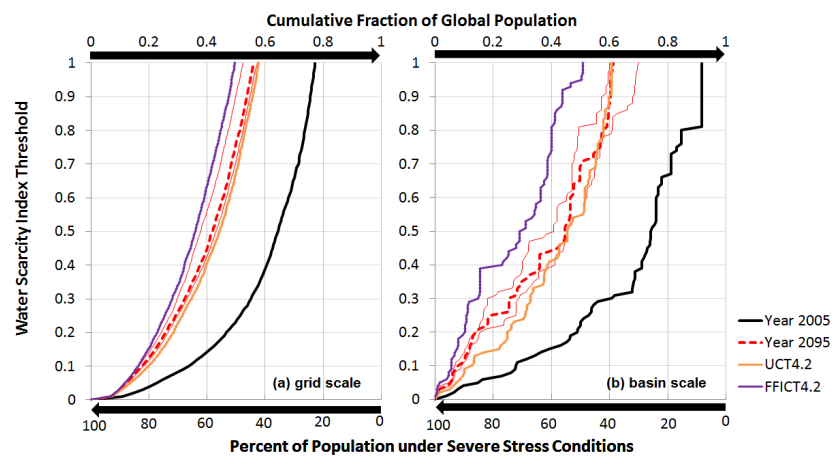

Figure 17. Shifts to the cumulative probability density function of the fraction of the global population living under different levels of scarcity (WSI). Water scarcity is estimated at the grid (a) and basin (b) scales; the thin lines reflect the uncertainty corresponding to any one of the four GCMs instead of the ensemble mean.

conditions (1995-2000), our estimates in year 2005 generally fall within the documented range. Figure 19 shows a comparison of the estimated percentage of the global population living in grids (Fig. 19a) and basins (Fig. 19b), and under different thresholds of water scarcity conditions with previous estimates from the literature (Wada et al., 2011, and baselines therein; Arnell et al., 2002, 2011; Alcamo et al., 2007). The spread in our results reflect the uncertainty arising from relying on each of the GCMs separately and the various climate policies, both singly and in tandem. Although we found that variation in water availability due to different emission policies is less than those attributed to using different GCMs (Fig. 5), Fig. 19 shows the opposite in terms of estimates of the global population living under 

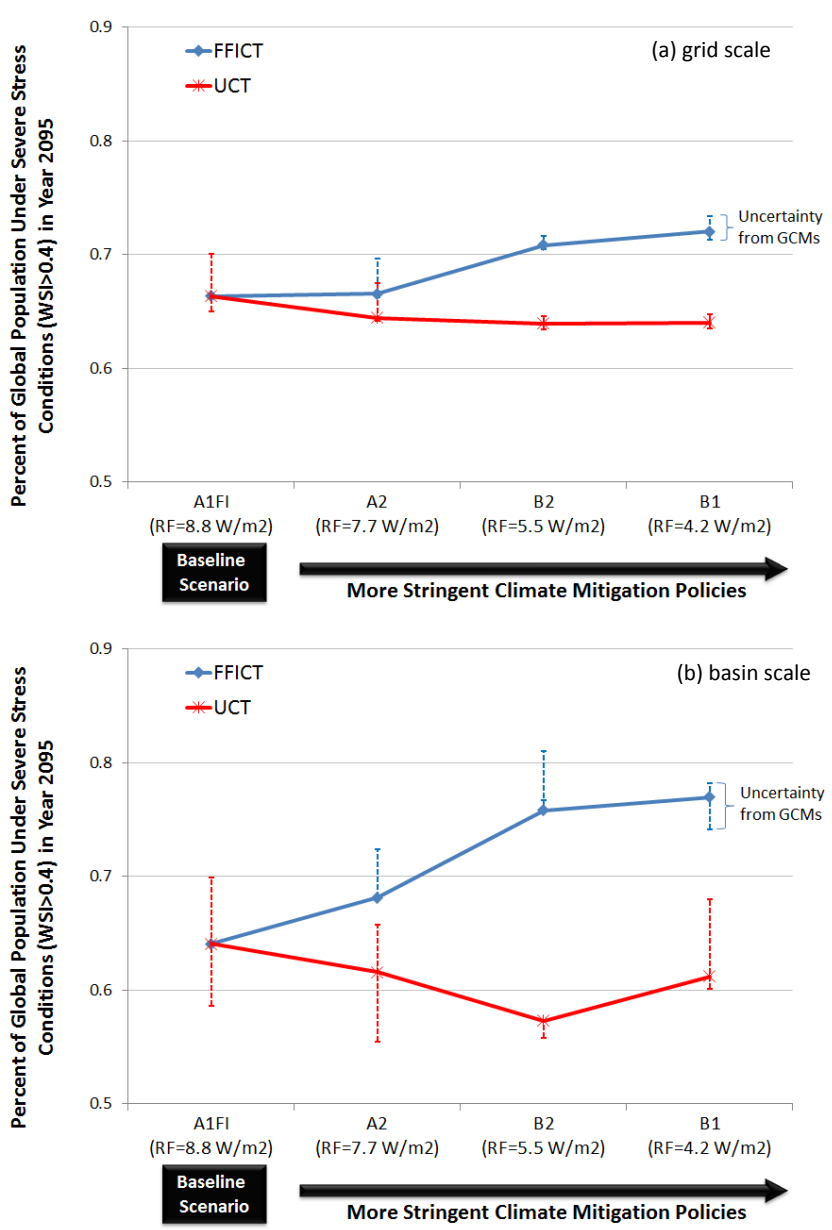

Figure 18. Percent of population living under severe water scarcity conditions in year 2095 under different climate policies and with increasing stringency; error bars reflect the level of uncertainty if a single GCM is used instead of the ensemble of four GCMs.

severe water scarcity in 2095 , in other words there is more uncertainty from the various emission scenarios (policy scenarios) than from those attributed to using different GCMs, thus signifying that changes in water demand are dominating changes in water supply. This result is consistent with the finding of Vörösmarty et al. (2000) that population growth plays a larger role in water scarcity than climate change in 2025. However, comparing the relative contributions of climate change, climate mitigation policies and socioeconomic drivers on water scarcity far longer in the future are yet to be tackled. Figure 20 shows a comparison between the grid- and basin-scale results along with other estimates from the literature for severely water-stressed global populations. Grid-based estimates overestimate scarcity as compared to basin-based estimates but that difference diminishes as scarcity increases. Note that the wide range of historical results (Figs. 19 and 20) signifies the wide level of uncertainty in such estimates. Uncertainty can arise from the method of estimating total water availability, projecting wa-
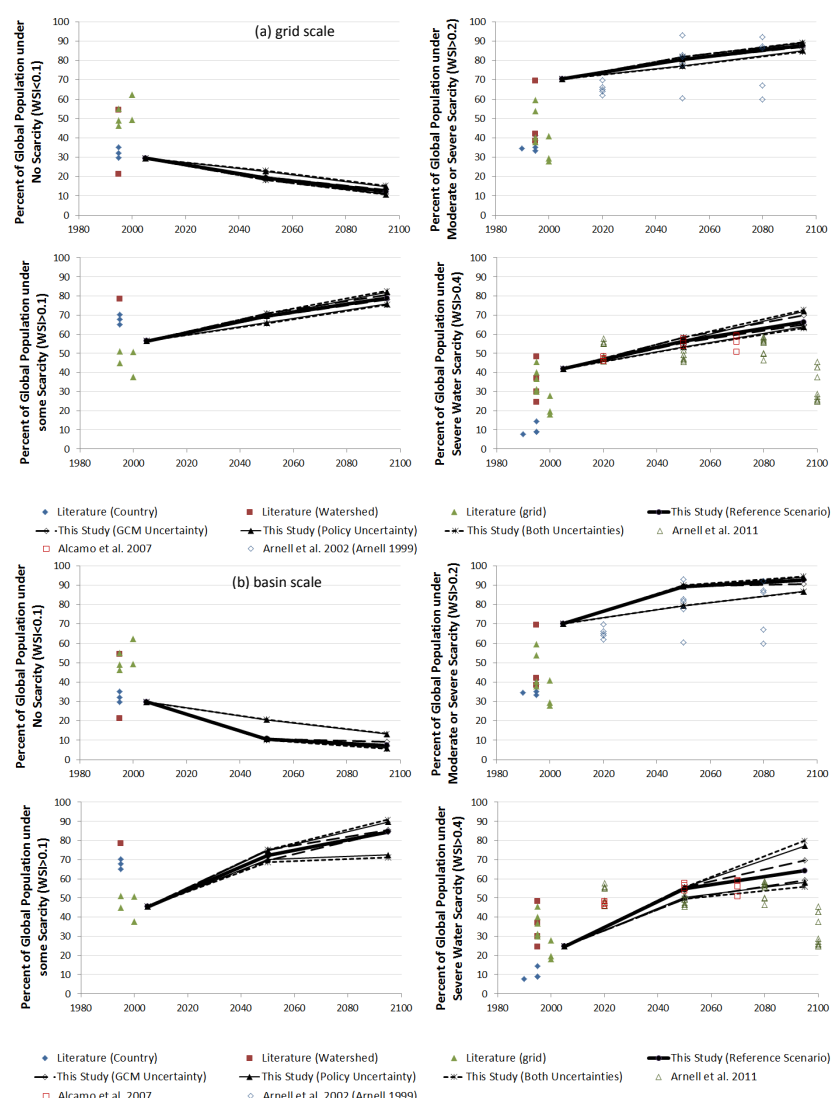

- Literature (Country)

$\rightarrow$ - This Study (GCM Un

- Literature (Watershed)

Arnellet al. 2002 (Arnell 1999)

Literature (grid) $\rightarrow-$ his study (Reeter

Figure 19. Comparison of the estimated percent of global population living different thresholds of water scarcity conditions with previous estimates from the literature (Wada et al., 2011, and references therein; Arnell et al., 2002, 2011; Alcamo et al., 2007). The spread in our results reflect the uncertainty arising from relying on each of the GCMs separately and the various climate policies, both singly and in tandem; the shape denotes the spatial scale of estimating WSI (blue diamonds: country scale; red squares: watershed scale; and green triangles: grid scale); solid points reflect assessments of current or historical scarcity conditions; empty shapes denote projections in the future.

ter demand, selecting spatial and temporal scales for the water scarcity calculations, and to downscaling demands to the appropriate scale. Future research should quantify the relative effect of those sources of uncertainties on water scarcity. Also, in this study we assume static population density maps; accounting for the diffusion of population over time is important to improve the realism of our findings.

\section{Conclusions}

To quantify changes in future water scarcity, estimates of water availability from the new gridded water-balance global hydrologic model (GWAM) are compared with global water demands as modeled in GCAM. The six water demand sectors in GCAM (irrigation, livestock, domestic, electricity 


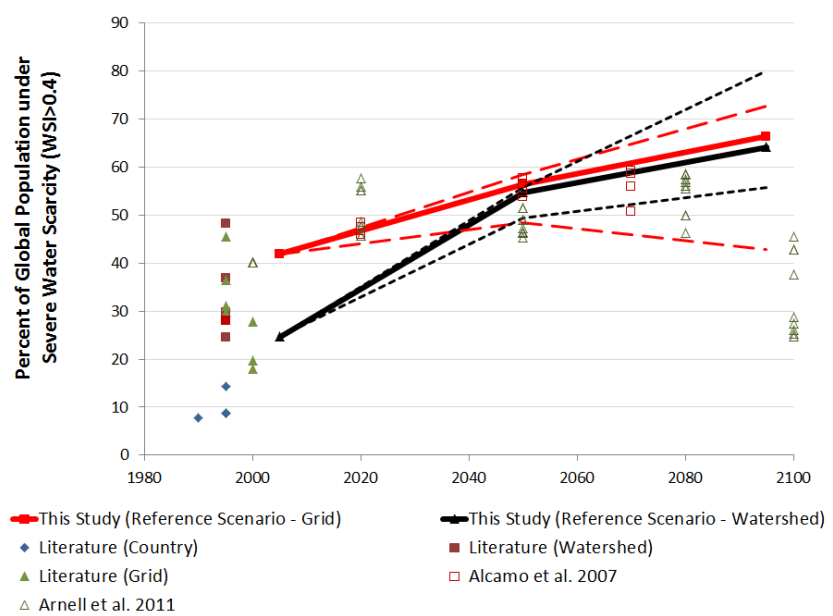

Figure 20. Comparison of the estimated percent of global population under severe water stress in grid cells (black lines) and basin areas (red lines) along with previous estimates from the literature (Wada et al., 2011, and references therein; Arnell et al., 2002, 2011; Alcamo et al., 2007); the spread in our results reflect the uncertainty arising from relying on each of the GCMs separately and the various climate policies (dashed lines); the shape denotes the spatial scale of estimating WSI (blue diamonds: country scale; red squares: watershed scale; and green triangles: grid scale); solid points reflect assessments of current or historical scarcity conditions; empty shapes denote projections in the future.

generation, primary energy production, and manufacturing) provide the total annual water demand divided by sector, subsector, technology, and region that are associated with any GCAM reference or policy stabilization scenario. Six policy scenarios (two types and three targets of radiative forcings) are simulated in GCAM along with the associated water demands and supply projections, and estimates are made of their impacts on water scarcity and thus the populations facing more or less water scarcity conditions. The results indicate that water scarcity shifts differently with the increasing stringency of the adopted climate change mitigation policies in term of emission targets. When compared to a baseline scenario (no climate policy), water scarcity declines under a UCT mitigation policy, while it increases with a FFICT mitigation scenario by the year 2095, mainly due to variations in prevailing bioenergy productions. Under the UCT scenario, although with population growth coupled with increasing energy and food demands, water scarcity is likely to increase due to higher water demands (when compared to the reference scenario), while less water scarcity is projected on a global average but with spatial variations. For the FFICT scenarios, more scarcity is projected with more stringent climate policies. Thus, depending on the adopted policy type and stringency level, climate mitigation could lead to more or less water scarcity.

For assessing global water scarcity under current and future scenarios, there are several unique advantages to the ap- proach adopted in this study. Most previous modeling efforts have focused on specific components of the humanearth system and assumed the behavior of remaining components by applying projected trends, output of other models, or reanalysis data. In contrast, in this study, we model water demand and availability within an internally consistent integrated assessment modeling framework with structural representations for the demands of water in most of the major water demand sectors. Thus, both water demand and supply are driven from the same set of assumptions about population and income growth, technological change, and emission scenario. This is important because human society and the natural environment are interconnected: changes to the climate and natural systems will require society to adapt, and its adaptation efforts will affect the global environment in return. This interplay between natural and socio-economic systems determines the entire system's evolution and makes the representation of the corresponding feedbacks critical to the development of appropriate adaptation and mitigation strategies (Davies and Simonovic, 2011).

Additionally, reconciling water demand and supply in an internally consistent integrated assessment framework represents an important advance in the integrated assessment modeling field, as water is generally not explicitly modeled. With water balancing in GCAM, one can tackle the question of the adequacy of water availability under different climate change mitigation policies. Hejazi et al. (2013b) investigated the level of water demands in each GCAM region by the end of the 21st century under a set of six representative socioeconomic scenarios, while assuming constant water availability to current condition. In this paper, we extend that work by incorporating a global water availability model in GCAM to capture the effect of climate change on the amount of available water in conjunction of demands. The impact of climate change on water demands are not accounted for, and the water demand scenario in this study is a slightly modified version of the POP14/MDG- scenario in Hejazi et al. (2013b) to match closely the emission trajectory used in simulating the global hydrologic model (e.g., SRES A1Fi). Hejazi et al. (2013b) found that water demands in the Middle East and India have already or will exceed their annual renewable water availability during the 21 st century. The incorporation of the global hydrologic model (i.e., the effect of climate change on hydrology) did not change the previous outcome. Thus, although the amount of water spatially available changes over time, growing water demand pressures generally impose a stronger influence on water scarcity conditions, especially in regions such as India and the Middle East. These high waterscarcity values indicate that the scenario is likely infeasible from a water perspective, since such high water stress would typically lead to the adoption of water conservation technologies, with implications for other human choices (e.g., food, energy).

For example, under the most stringent FFICT scenario (FFICT4.2), global water withdrawals increase from 
$3710 \mathrm{~km}^{3} \mathrm{yr}^{-1}$ in 2005 to $25357 \mathrm{~km}^{3} \mathrm{yr}^{-1}$ in 2095 . But, is this quantity even physically feasible? Postel et al. (1996) estimated that out of the of the $40700 \mathrm{~km}^{3} \mathrm{yr}^{-1}$ global mean annual runoff volume, $7774 \mathrm{~km}^{3} \mathrm{yr}^{-1}$ is inaccessible for human use, $20426 \mathrm{~km}^{3}$ year ${ }^{-1}$ is uncaptured floodwater that flows directly to the world oceans, and only the remaining $12500 \mathrm{~km}^{3}$ year $^{-1}$ is geographically and temporally accessible runoff, of which $2350 \mathrm{~km}^{3}$ year ${ }^{-1}$ is needed for instream water uses. Thus, humans' access to renewable water is approximately $10150 \mathrm{~km}^{3}$ year $^{-1}$. Although this quantity may have increased over the past two decades due to new reservoir storage capacity, especially in developing regions, Postel's analysis suggests that all scenarios, including the baseline scenario, are potentially infeasible in the second half of the century. Recall that global water withdrawals range between 8843 and $9276 \mathrm{~km}^{3}$ year $^{-1}$ in 2050 and between 12533 and $25357 \mathrm{~km}^{3}$ year $^{-1}$ in 2095 . This also highlights some of the limitations of the model to represent the feedback from water supply and demand imbalances on human choices with regard to their diets, energy use, and prevailing technologies. Furthermore, in all the scenarios, the prevalence of water technologies (e.g., cooling system, irrigation efficiency) is exogenously entered into the model, however, the likely strong competition for water among the competing users and the mounting scarcity over time could cause differences in the evolution of certain technologies from how they are assumed to function in this framework. Thus, a market-based or an allocation-based approach is necessary to permit the modeling framework to endogenously choose among various water technologies instead of being exogenously fed into the model. Also, future research should be directed at incorporating water shortage feedbacks in GCAM to better understand how such stresses will propagate across the various human and natural systems in GCAM. Other advances to the framework can focus on the impact of warming on yield and crop water requirements, the effect of $\mathrm{CO}_{2}$ fertilization on crop water use efficiency, and the effect of elevating water temperatures in streams on cooling efficiencies, which are not accounted for in this study. Instream water requirements for ecosystems and recreational and navigational purposes are also not accounted for as part of the global total demand and will need to be included in the future. When comparing water demand and supply at large regional scales, water scarcity is likely to be averaged out, as GCAM regions that contain much more water available than demanded annually may still encompass sub-regions or grids that experience extreme stress conditions. To better characterize scarcity, in this study we downscale the water demands from the GCAM regions and AEZs to the grid scale. Many grid cells exhibit higher water demands than the amount of runoff available. As shown in Fig. 14, the percentage of global population experiencing WSI $>1.0$ (i.e., TWD $>$ TWA) increases from 8 to $23 \%$ in 2005 to $28-36 \%$ and $39-44 \%$ in years 2050 and 2095, respectively; the higher range estimates are associated with grid-based estimates of WSI (Fig. 14a). Note however that because large population densities tend to occur at the main stem of large rivers that drain large regions, and because river routing is not implemented in GWAM, results are likely to overestimate the percentage of populations facing water scarcity conditions. Thus, water scarcity calculations are also performed at the basin scale to complement the gridscale results. Also, the results in this paper reflect an extreme population scenario, and water scarcity is likely to be alleviated when testing less populated scenarios. The effects of different socioeconomic and emissions scenarios on global water scarcity assessments are not fully understood, but are likely to influence water scarcity conditions. Furthermore, although Table 4 indicates that the scarcity estimates in 2005 are still within the range of uncertainty in current estimates, the projected estimates in scarcity along with the cited literature values exhibit a wide range of uncertainty. Thus, quantifying the various sources of uncertainty is an important step to improve the reliability of water scarcity estimates in the future.

Uncertainty in water scarcity estimates could arise from several factors, such as the amount of water available (i.e., model uncertainty of global hydrologic models and GCM predictions), the adopted socioeconomic and technology assumptions, projections of global water demands, downscaling techniques of water demands to match the scale of the water availability modeling exercise (watershed or grid), and the adopted spatial and temporal resolutions at which water scarcity is computed. Studies that perform inter-model comparisons among global hydrologic models can help identify the major sources of uncertainty in water availability estimates. Gleick (2003) and Hejazi et al. (2013b) concluded that there is a wide range of variations in global water demand projections. Wada et al. (2011) found that a shorter temporal scale leads to higher estimates of water scarcity globally, but their observed variation is still smaller than the level of variations observed in the literature. Finally, downscaling techniques are generally simplistic; more advanced models that capture migration and population dynamics, and more accurate downscaling of industrial (e.g., energy, electricity, and manufacturing) water demands are warranted. 


\section{Appendix A: Monthly pet calculations (Hargreaves method)}

The following equations describe the calculations of monthly potential evapotranspiration $\left(\mathrm{PET}_{\mathrm{m}}\right)$ using the Hargreaves method. First, PET is computed at the daily scale using Equation A1.

$\mathrm{PET}_{\mathrm{d}}=0.0023 \cdot \mathrm{Ra} \cdot\left(T_{\mathrm{a}}+17.8\right) \cdot T_{\mathrm{r}}^{0.5}$,

where $\mathrm{PET}_{\mathrm{d}}$ is the potential evapotranspiration in $\mathrm{mm} / \mathrm{day}$. To convert to monthly $\left(\mathrm{PET}_{\mathrm{m}}\right), \mathrm{PET}_{\mathrm{d}}$ is multiplied by the number of days $(n)$ in each month $\left(\operatorname{PET}_{\mathrm{m}}=n \cdot \operatorname{PET}_{\mathrm{d}}\right) . T_{\mathrm{a}}$ is the average daily temperature in Celsius. $T_{\mathrm{r}}$ is the range between maximum and minimum daily temperatures in Celsius. $\mathrm{Ra}$ is the extraterrestrial solar radiation in $\mathrm{mm} \mathrm{day}^{-1}$.

$$
\begin{aligned}
\mathrm{Ra} & =\frac{(24) \cdot(60)}{\pi} \lambda \cdot G_{\mathrm{sc}} \cdot d_{\mathrm{r}} \cdot\left[w_{\mathrm{s}} \cdot \sin (\varphi) \cdot \sin (\delta)\right. \\
& \left.+\cos (\varphi) \cdot \cos (\delta) \cdot \sin \left(w_{\mathrm{s}}\right)\right]
\end{aligned}
$$

$\lambda$ is the corresponding equivalent evaporation to convert $\mathrm{Ra}$ from $\mathrm{MJ} \mathrm{m}^{-2}$ day $^{-1}$ to $\mathrm{mm} \mathrm{day}^{-1}[\lambda=0.408], G_{\mathrm{sc}}$ is the solar constant $\left[G_{\mathrm{sc}}=0.0820 \mathrm{MJ}^{-2} \mathrm{~min}^{-1}\right], d_{\mathrm{r}}$ is the inverse relative distance Earth-Sun, $w_{\mathrm{s}}$ is the sunset hour angle (in radians), $\varphi$ is the latitude (in radians), and $\delta$ is the solar declination (in radians). The inverse relative distance Earth-Sun $\left(d_{\mathrm{r}}\right)$ is computed using Equation A3, where $J$ is the number of the day in the year between 1 (1 January) and 365 (31 December).

$d_{\mathrm{r}}=1+0.33 \cdot \cos \left(\frac{2 \pi}{365} \cdot J\right)$

\begin{tabular}{|c|c|}
\hline $\mathrm{PET}_{\mathrm{d}}$ : & Daily potential evapotranspiration in mm day \\
\hline $\mathrm{PET}_{\mathrm{m}}:$ & $\begin{array}{l}\text { Monthly potential evapotranspiration in } \\
\text { mm month }\end{array}$ \\
\hline$n:$ & Number of days in each month \\
\hline Ra: & Extraterrestrial solar radiation in $\mathrm{mm}_{\mathrm{day}}{ }^{-1}$ \\
\hline$T_{\mathrm{a}}:$ & Average daily temperature in Celsius \\
\hline$T_{\mathrm{r}}:$ & $\begin{array}{l}\text { Range between maximum and minimum daily } \\
\text { temperatures in Celsius }\end{array}$ \\
\hline$G_{\text {sc: }}$ & Solar constant $\left[=0.0820 \mathrm{MJ} \mathrm{m}^{-2} \mathrm{~min}^{-1}\right]$ \\
\hline$\lambda:$ & $\begin{array}{l}\text { Corresponding equivalent evaporation to convert } \\
\mathrm{Ra} \text { from } \mathrm{MJ} \mathrm{m}^{-2} \text { day }^{-1} \text { to } \mathrm{mm} \mathrm{day}^{-1}[=0.408]\end{array}$ \\
\hline$J:$ & Julian day in the year $(1-365)$ \\
\hline$d_{\mathrm{r}}:$ & Inverse relative distance Earth-Sun \\
\hline$w_{\mathrm{s}}:$ & Sunset hour angle (in radians) \\
\hline$\varphi:$ & Latitude (in radians) \\
\hline$\delta:$ & Solar declination (in radians) \\
\hline
\end{tabular}

Table A1. Nomenclature

Solar declination $(\delta)$ is the line of latitude over which the sun is directly overhead on any given day. Solar declination changes day to day due the Earth's revolution around the Sun and is computed using Eq. (A4).

$\delta=0.409 \cdot \sin \left(\frac{2 \pi}{365} \cdot J-1.39\right)$

The sunset hour angle $\left(w_{\mathrm{S}}\right)$ (in radians) is computed using equation A5.

$w_{\mathrm{s}}=\arccos (-\tan (\varphi) \cdot \tan (\delta))$

Equation (A2) can be simplified by replacing all constants with a single coefficient.

$$
\begin{aligned}
\mathrm{Ra} & =15.392 \cdot d_{\mathrm{r}} \cdot\left[w_{\mathrm{s}} \cdot \sin (\varphi) \cdot \sin (\delta)\right. \\
& \left.+\cos (\varphi) \cdot \cos (\delta) \cdot \sin \left(w_{\mathrm{s}}\right)\right]
\end{aligned}
$$


Acknowledgements. The authors are grateful for research support provided by the Integrated Assessment Research Program (IARP) and the Earth System Modeling (ESM) Program in the Office of Science of the US Department of Energy (DOE SC). This research used Evergreen computing resources at the Pacific Northwest National Laboratory's Joint Global Change Research Institute at the University of Maryland in College Park, which is supported by DOE SC-IARP. Pacific Northwest National Laboratory is operated by Battelle for the US Department of Energy under contract DE-AC05-76RL01830. The views and opinions expressed in this paper are those of the authors alone.

Edited by: A. Ghadouani

\section{References}

Alcamo, J. and Henrichs, T.: Critical regions: A model-based estimation of world water resources sensitive to global changes, Aquatic Sciences - Research Across Boundaries, 64, 352-362, doi:10.1007/p100012591, 2002.

Alcamo, J., Döll, P., Kaspar, F., and Siebert, S.: Global Change and Global Scenarios of Water Use and Availability: An Application of WaterGAP1.0, University of Kassel, Germany, 1997.

Alcamo, J., Doli, P., Henrichs, T., Kaspar, F., Lehner, B., Rosch, T., and Siebert, S.: Development and testing of the WaterGAP 2 global model of water use and availability, Hydrol. Sci. J., 48, 317-337, doi:10.1623/hysj.48.3.317.45290, 2003a.

Alcamo, J., Döll, P., Henrichs, T., Kaspar, F., Lehner, B., Rösch, T., and Siebert, S.: Global estimates of water withdrawals and availability under current and future "business-as-usual" conditions, Hydrol. Sci. J., 48, 339-348, doi:10.1623/hysj.48.3.339.45278, 2003b.

Alcamo, J., Flörke, M., and Marker, M.: Future long-term changes in global water resources driven by socio-economic and climatic changes, Hydrol. Sci. J., 52, 247-275, doi:10.1623/hysj.52.2.247, 2007.

AQUASTAT Database: FAO's global information system on water and agriculture, available at: http://www.fao.org/nr/water/ aquastat/main/index.stm, last access: December, 2012.

Arnell, N.: Climate change and global water resources, Global Environ. Change, 9, Supplement 1, S31-S49, doi:10.1016/s09593780(99)00017-5, 1999a.

Arnell, N.: A simple water balance model for the simulation of streamflow over a large geographic domain, J. Hydrol., 217, 314335, doi:10.1016/s0022-1694(99)00023-2, 1999b.

Arnell, N.: Climate change and global water resources: SRES emissions and socio-economic scenarios, Global Environ. Change, 14, 31-52, doi:10.1016/j.gloenvcha.2003.10.006, 2004.

Arnell, N. W., Cannell, M. G. R., Hulme, M., Kovats, R. S., Mitchell, J. F. B., Nicholls, R. J., Parry, M. L., Livermore, M. T. J., and White, A.: The Consequences of $\mathrm{CO}_{2}$ Stabilisation for the Impacts of Climate Change, Clim. Change, 53, 413-446, 2002.

Arnell, N., van Vuuren, D., and Isaac, M.: The implications of climate policy for the impacts of climate change on global water resources, Global Environ. Change, 21, 592-603, doi:10.1016/j.gloenvcha.2011.01.015, 2011.
Berndes, G.: Bioenergy and water - the implications of large-scale bioenergy production for water use and supply, Global Environ. Change, 12, 253-271, doi:10.1016/s0959-3780(02)00040-7, 2002.

Berndes, G.: Water demand for global bioenergy production: trends, risks and opportunities, WBGU, Berlin, 2008.

Brenkert, M., Smith, S. , Kim, S., and Pitcher, H.: Model Documentation for the MiniCAM, PacificNorthwest National Laboratory, Richland, Washington, 2003.

Brown, A. and Matlock, M.: A Review of Water Scarcity Indices and Methodologies: The Sustainability Consortium, University of Arkansas, 2011.

Bruinsma, J. E.: World agriculture: towards 2015/2030 - An FAO perspective, FAO, Rome, London, 2003.

Cabré, M., Solman, S., and Nuñez, M.: Creating regional climate change scenarios over southern South America for the 2020's and 2050's using the pattern scaling technique: validity and limitations, Clim. Change, 98, 449-469, doi:10.1007/s10584-0099737-5, 2010.

Cai, X. and Rosegrant, M. W.: Global water demand and supply projections, Part 1: a modeling approach, Water Int., 27, 159169, 2002.

Chaturvedi, V., Hejazi, M., Edmonds, J., Clarke, L., Kyle, P., Davies, E., and Wise, M.: Climate mitigation policy implications for global irrigation water demand, Mitigation and Adaptation Strategies for Global Change, Springer Netherlands, doi:10.1007/s11027-013-9497-4, 2013.

Clarke, L., Lurz, J., Wise, M., Edmonds, J., Kim, S., Pitcher, H., and Smith, S.: Model Documentation for the MiniCAM Climate Change Science Program Stabilization Scenarios, Pacific Northwest National Laboratory Richland, WA, USA, 2007.

Davies, E. and Simonovic, S.: Global water resources modeling with an integrated model of the social-economicenvironmental system, Adv. Water Resour., 34, 684-700, doi:10.1016/j.advwatres.2011.02.010, 2011.

Davies, E., Kyle, P., and Edmonds, J.: An integrated assessment of global and regional water demands for electricity generation to 2095, Adv. Water Resour., 52, 296-313, 2013.

de Fraiture, C.: Integrated water and food analysis at the global and basin level. An application of WATERSIM, Water Resour. Manage., 185-198, doi:10.1007/s11269-006-9048-9, 2007.

Döll, P. and Fiedler, K.: Global-scale modeling of groundwater recharge, Hydrol. Earth Syst. Sci., 12, 863-885, doi:10.5194/hess-12-863-2008, 2008.

Edmonds, J. and Reilly, J.: Global Energy: Assessing the Future, Oxford University Press, New York, 1985.

Elvidge, C. D., Baugh, K. E., Kihn, E. A., Kroehl, H. W., and Davis, E. R.: Mapping City Lights With Nighttime Data From the DMSP Operational Linescan System, Photogramm. Eng. Remote Sens., 63, 727-734, 1997a.

Elvidge, C. D., Baugh, K. E., Kihn, E. A., Kroehl, H. W., Davis, E. R., and Davis, C. W.: Relation between satellite observed visiblenear infrared emissions, population, economic activity and electric power consumption, Int. J. Remote Sens., 18, 1373-1379, doi:10.1080/014311697218485, 1997b.

ESRI: The Digital Chart of the World, Environmental Systems Research Institute Redlands, California, 1993. 
Falkenmark, M.: The Massive Water Scarcity Now Threatening Africa: Why Isn't It Being Addressed?, Ambio, 18, 112-118, 1989.

Falkenmark, M.: Forward to the Future: A Conceptual Framework for Water Dependence, Ambio, 28, 356-361, 1999.

Falkenmark, M., Berntell, A., Jägerskog, A., Lundqvist, J., Matz, M., and Tropp, H.: On the verge of a new water scarcity: A call for good governance and human ingenuity, Stockholm Int. Water Inst., Stockholm, 2007.

FAO: Digital soil of the world and derived soil properties, Rome, 1998.

FAO: Water Resources and Irrigation in Africa, Initially published in "Atlas of Water Resources and irrigation in Africa (CDROM)", FAO, Rome, 2001.

FAO: Digital soil map of the world and derived soil properties, [Version 3.5] Edn., FAO, Rome, Italy, 2003.

Fekete, B. M., Vörösmarty, C. J., and Grabs, W.: Global composite runoff fields based on observed river discharge and simulated water balances, Global Runoff Data Centre, Koblenz, Germany, 2000.

Flörke, M. and Alcamo, J.: European Outlook on Water Use, Center for Environmental Systems Research, University of Kassel, 2004.

Gerbens-Leenes, P., Hoekstra, A., and van der Meer, T.: The water footprint of energy from biomass: A quantitative assessment and consequences of an increasing share of bioenergy in energy supply, Ecol. Econom., 68, 1052-1060, doi:10.1016/j.ecolecon.2008.07.013, 2009.

Gerten, D., Schaphoffa, S., Haberlandtb, U., Luchta, W., and Sitch, S.: Terrestrial vegetation and water balance - hydrological evaluation of a dynamic global vegetation model, J. Hydrol., 286, 249-270, 2004.

Gleeson, T., Wada, Y., Bierkens, M. F. P., and van Beek, L. P. H.: Water balance of global aquifers revealed by groundwater footprint, Nature, 488, 197-200, http://www.nature.com/nature/journal/v488/n7410/abs/ nature11295.html\#supplementary-information, 2012.

Gleick, P.: WATER USE, Annu. Rev. Environ. Resour., 28, 275314, doi:10.1146/annurev.energy.28.040202.122849, 2003.

Hanasaki, N., Kanae, S., Oki, T., Masuda, K., Motoya, K., Shirakawa, N., Shen, Y., and Tanaka, K.: An integrated model for the assessment of global water resources - Part 1: Model description and input meteorological forcing, Hydrol. Earth Syst. Sci., 12, 1007-1025, doi:10.5194/hess-12-1007-2008, 2008a.

Hanasaki, N., Kanae, S., Oki, T., Masuda, K., Motoya, K., Shirakawa, N., Shen, Y., and Tanaka, K.: An integrated model for the assessment of global water resources - Part 2: Applications and assessments, Hydrol. Earth Syst. Sci., 12, 1027-1037, doi:10.5194/hess-12-1027-2008, 2008b.

Hargreaves, G. H. and Allen, R. G.: History and evaluation of Hargreaves evapotranspiration equation, J. Irrig. Drain. Eng., 129, 53-63, 2003.

Hargreaves, G. L., Hargreaves, G. H., and Riley, J. P.: Irrigation water requirements for Senegal River Basin, J. Irrig. Drain. Eng., 111, 265-275, 1985.
Hayashi, A., Akimoto, K., Tomoda, T., and Kii, M.: Global evaluation of the effects of agriculture and water management adaptations on the water-stressed population, Mitig. Adapt. Strateg. Global Change, 18, 591-618, doi:10.1007/s11027-012-9377-3, 2013.

Hejazi, M., Edmonds, J., Chaturvedi, V., Davies, E., and Eom, J. Y.: Scenarios of global municipal water use demand projections over the 21st century, Hydrol. Sci. J., 58, 519-538, 2013 a.

Hejazi, M., Edmonds, J., Clarke, L., Kyle, P., Chaturvedi, V., Davies, E., Wise, M., Patel, P., Eom, J., and Calvin, K.: Long-term global water use projections using six socioeconomic scenarios in an integrated assessment modeling framework, Technol. Forecast. Social Change, 81, 205-226, doi:10.1016/j.techfore.2013.05.006, 2013b.

Hoff, H., Falkenmark, M., Gerten, D., Gordon, L., Karlberg, L., and Rockström, J.: Greening the global water system, J. Hydrol., 384, 177-186, doi:10.1016/j.jhydrol.2009.06.026, 2010.

Islam, M., Oki, T., Kanae, S., Hanasaki, N., Agata, Y., and Yoshimura, K.: A grid-based assessment of global water scarcity including virtual water trading, Water Resour. Manage., 21, 1933, doi:10.1007/s11269-006-9038-y, 2007.

Jackson, R. B., Carpenter, S. R., Dahm, C. N., McKnight, D. M., Naiman, R. J., Postel, S. L., and Running, S. W.: Water in a Changing World, Ecol. Applic., 11, 1027-1045, doi:10.1890/1051-0761(2001)011[1027:wiacw]2.0.co;2, 2001.

Kaczmarek, Z.: Water balance model for climate impact assessment, Acta Geophys. Pol., 61, 423-437, 1993.

Kim, S., Edmonds, J., Lurz, J., Smith, S., and Wise, M.: The objectoriented energy climate technology systems (ObjECTS) framework and hybrid modeling of transportation in the MiniCAM Long-term, global integrated assessment model, Energy J., 27, 63-92, 2006.

Kuhl, S. C. and Miller, J. R.: Seasonal River Runoff Calculated from a Global Atmospheric Model, Water Resour. Res., 28, 2020 2039, 1992.

Liang, X., Lettenmaier, D. P., Wood, E. F., and Burges, S. J.: A simple hydrologically based model of land surface water and energy fluxes for general circulation models, J. Geophys. Res., 99, 14415-14428, doi:10.1029/94jd00483, 1994.

Liang, X., Lettenmaier, D. P., and Wood, E. F.: One-dimensional statistical dynamic representation of subgrid spatial variability of precipitation in the two-layer variable infiltration capacity model, J. Geophys. Res., 101, 21403-21422, doi:10.1029/96JD01448, 1996.

Liu, J. and Yang, H.: Spatially explicit assessment of global consumptive water uses in cropland: Green and blue water, J. Hydrol., 384, 187-197, 2010.

Liu, J., Williams, J. R., Zehnder, A. J. B., and Yang, H.: GEPIC - modelling wheat yield and crop water productivity with high resolution on a global scale, Agr. Syst., 94, 478-493, 2007.

Liu, J., Zehnder, A. J. B., and Yang, H.: Global consumptive water use for crop production: the importance of green water and virtual water, Water Resour. Res., 45, W05428, doi:10.1029/2007WR006051, 2009.

Manabe, S.: Climate and the circulation. Part I: the atmospheric circulation and the hydrology of the Earth's surface, Mon. Weather Rev., 97, 739-774, 1969.

Miller, J. R. and Russell, G. L.: The Impact of Global Warming on River Runoff, J. Geophys. Res., 97, 2757-2764, 1992. 
Milly, P., Dunne, K., and Vecchia, A.: Global pattern of trends in streamflow and water availability in a changing climate, Nature, 438, 347-350, 2005.

Mitchell, T. D. and Jones, P. D.: An improved method of constructing a database of monthly climate observations and associated high-resolution grids, Int. J. Climatol., 25, 693-712, 2005.

Mitchell, T. D., Carter, T. R., Jones, P. D., Hulme, M., and New, M.: A comprehensive set of high-resolution grids of monthly climate for Europe and the globe: the observed record (1901-2000) and 16 scenarios (2001-2100), Tyndall Centre for Climate Change Research, University of East Anglia, Norwich, UK, 30 pp., 2004.

Monfreda, C., Ramankutty, N., and Foley, J. A.: Farming the planet: 2. Geographic distribution of crop areas, yields, physiological types, and net primary production in the year 2000, Global Biogeochem. Cy., 22, GB1022, doi:10.1029/2007gb002947, 2008.

Niu, G.-Y., Yang, Z.-L., Dickinson, R. E., and Gulden, L. E.: A simple TOPMODEL-based runoff parameterization (SIMTOP) for use in global climate models, J. Geophys. Res., 110, D21106, doi:10.1029/2005JD006111, 2005.

Oki, T. and Kanae, S.: Global Hydrological Cycles and World Water Resources, Science, 313, 1068-1072, doi:10.1126/science.1128845, 2006.

Oki, T., Nishimura, T., and Dirmeyer, P.: Assessment of land surface models by runoff in major river basins of the globe using Total Runoff Integrating Pathways (TRIP), J. Meteorol. Soc. Japan, 77, 235-255, 1999.

Oki, T., Agata, Y., Kanae, S., Saruhashi, T., Yang, D., and Musiake, K.: Global assessment of current water resources using total runoff integrating pathways, Hydrol. Sci. J., Special issue: Can Science and Society Avert the World Water Crisis in the 21st Century?, 46, 983-995, doi:10.1080/02626660109492890, 2001.

Portmann, F., Siebert, S., Bauer, C., and Döll, P.: Global data set of monthly growing areas of 26 irrigated crops, University of Frankfurt, Germany, 2008.

Postel, S. L., Daily, G. C., and Ehrlich, P. R.: Human Appropriation of Renewable Fresh Water, Science, 271, 785-788, doi:10.1126/science.271.5250.785, 1996.

Ramankutty, N., Evan, A. T., Monfreda, C., and Foley, J. A.: Farming the planet: 1. Geographic distribution of global agricultural lands in the year 2000, Global Biogeochem. Cy., 22, GB1003, doi:10.1029/2007gb002952, 2008 .

Raper, S. C. B., Wigley, T. M. L., and Warrick, R. A.: Global sea level rise: past and future, in: Sea-level rise and coastal subsidence: causes, consequences and strategies, edited by: Milliman, J. D. and Haq, B. U., Kluwer Academic, Dordrecht, 1996.

Raskin, P., Gleick, P., Kirshen, P., Pontius, G., and Strzepek, K.: Water Futures: Assessment of Long-range Patterns and Prospects, Stockholm, Sweden: Stockholm Environment Institute, 1997.

Rost, S., Gerten, D., Bondeau, A., Lucht, W., Rohwer, J., and Schaphoff, S.: Agricultural green and blue water consumption and its influence on the global water system, Water Resour. Res., 44, W09405, doi:10.1029/2007wr006331, 2008.

Shen, Y., Oki, T., Utsumi, N., Kanae, S., and Hanasaki, N.: Projection of future world water resources under SRES scenarios: water withdrawal / Projection des ressources en eau mondiales futures selon les scénarios du RSSE: prélèvement d'eau, Hydrol. Sci. J., 53, 11-33, doi:10.1623/hysj.53.1.11, 2008.
Siebert, S., Döll, P., Feick, S., Hoogeveen, J., and Frenken, K.: Global Map of Irrigation Areas version 4.0.1, Johann Wolfgang Goethe University, Frankfurt am Main, Germany/Food and Agriculture Organization of the United Nations, Rome, Italy, 2007.

Sperna Weiland, F. C., van Beek, L. P. H., Kwadijk, J. C. J., and Bierkens, M. F. P.: The ability of a GCM-forced hydrological model to reproduce global discharge variability, Hydrol. Earth Syst. Sci., 14, 1595-1621, doi:10.5194/hess-14-15952010, 2010.

SRES: Special Report on Emissions Scenarios: A special report of Working Group III of the Intergovernmental Panel on Climate Change, edited by: Nakićenović, N. and Swart, R., Cambridge University Press, 2000.

Tobler, W., Deichmann, U., Gottsegen, J., and Maloy, K.: The Global Demography Project, National Center for Geographic Information and Analysis, Santa Barbara CA, 1995.

Varghese, S.: Biofuels and global water challenges, Institute for Agriculture Trade and Policy, USA, 2007.

Viviroli, D., Dürr, H. H., Messerli, B., Meybeck, M., and Weingartner, R.: Mountains of the world, water towers for humanity: Typology, mapping, and global significance, Water Resour. Res., 43, W07447, doi:10.1029/2006wr005653, 2007.

Vörösmarty, C., Moore III, B., Grace, A., Gildea, M., Melillo, J., and Peterson, B.: Continental scale models of water balance and fluvial transport: An application of South America, Global Biogeochem. Cy., 3, 241-265, 1989.

Vörösmarty, C., Federer, C., and Schloss, A.: Potential evaporation functions compared on US watersheds: Possible implications for global-scale water balance and terrestrial ecosystem modeling, J. Hydrol., 207, 147-169, doi:10.1016/s0022-1694(98)00109-7, 1998.

Vörösmarty, C., Green, P., Salisbury, J., and Lammers, R.: Global Water Resources: Vulnerability from Climate Change and Population Growth, Science, 289, 284-288, doi:10.1126/science.289.5477.284, 2000.

Wada, Y., van Beek, L. P. H., van Kempen, C. M., Reckman, J. W. T. M., Vasak, S., and Bierkens, M. F. P.: Global depletion of groundwater resources, Geophys. Res. Lett., 37, L20402, doi:10.1029/2010g1044571, 2010.

Wada, Y., van Beek, L., Viviroli, D., Dürr, H., Weingartner, R., and Bierkens, M.: Global monthly water stress: 2. Water demand and severity of water stress, Water Resour. Res., 47, W07518, doi:10.1029/2010wr009792, 2011.

Widén-Nilsson, E., Halldin, S., and Xu, C.-Y.: Global water-balance modelling with WASMOD-M: Parameter estimation and regionalisation, Journal of Hydrology, 340, 105-118, 2007.

Wigley, T. M. L. and Raper, S. C. B.: Implications for climate and sea level of revised IPCC emissions scenarios, Nature, 357, 293-300, 1992.

Wigley, T. M. L. and Raper, S. C. B.: Reasons for Larger Warming Projections in the IPCC Third Assessment Report, J. Climate, 15, 2945-2952, doi:10.1175/15200442(2002)015<2945:rflwpi>2.0.co;2, 2002.

Wint, G. and Robinson, T.: Gridded livestock of the world, Food and Agriculture Organization (FAO), report 131, Rome, 2007.

Wise, M., Calvin, K., Thomson, A., Clarke, L., Bond-Lamberty, B., Sands, R., Smith, S. J., Janetos, A., and Edmonds, J.: Implications of Limiting $\mathrm{CO}_{2}$ Concentrations for Land Use and Energy, Science, 324, 1183-1186, 2009. 
WMO, W. M. O.: Comprehensive Assessment of the Freshwater Resources of the World, Stockholm Environment Institute, Stockholm, Sweden, 1997.

Yang, D., Kanae, S., Oki, T., and Musiake, K.: Expanding the distributed hydrological modelling to continental scale, IAHS Publication, 270, 125-134, 2001.

Yates, D.: WatBal - An Integrated Water Balance Model for Climate Impact Assessment of River Basin Runoff, HIIASA International Institute for Applied Systems Analysis Laxenburg, Austria, 1994.
Yates, D. N.: WatBal: An Integrated Water Balance Model for Climate Impact Assessment of River Basin Runoff, Water Resour Develop., 12, 121-139, 1996.

Zomer, R. J., Trabucco, A., van Straaten, O., and Bossio, D. A.: Carbon, land and water: A global analysis of the hydrologic dimensions of climate change mitigation through afforestation/reforestation, International Water Management Institute, Colombo, Sri Lanka, 44 pp., available at: http://www.iwmi.cgiar.org/Publications/IWMI_Research_ Reports/PDF/pub101/RR101.pdf, 2006. 